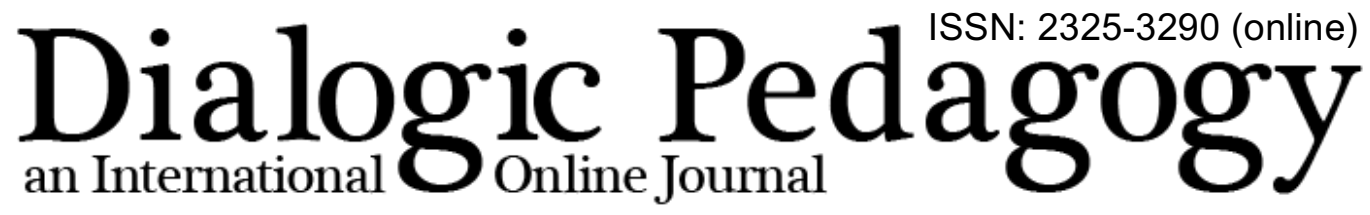

\section{Legitimacy of non-negotiable imposition in diverse approaches to education}

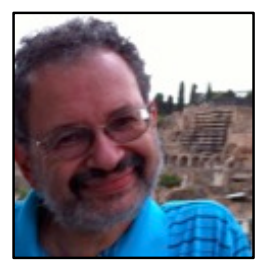

\author{
Eugene Matusov \\ University of Delaware, USA
}

\begin{abstract}
Modern conventional education is full of impositions on its students. Schools often impose on students where they must be, what they must do and learn, how they must behave and communicate in the places and the ways that the teacher and school define. However, the legitimacy of this imposition - how much of this imposition is necessary, useful, justified, and desirable for education itself - has not been specifically discussed and analyzed yet. The legitimacy of this imposition is especially important to do for innovative education, evaluating and reconsidering its goals and practices of education. Analysis of imposition in education can help to address important questions of why oppression, alienation, if not pedagogical violence, are so prevalent in organized education and whether this is can be avoided or not. The goal of this paper is to consider different approaches to non-negotiable imposition in education, its legitimacy, and justifications and analyze their pros and cons. I consider Totalizing conventional, Capitalist, Progressive, Democratic, Anarchist, and Communitarian educational approaches to non-negotiable imposition and its legitimacy from an educational perspective.
\end{abstract}

Eugene Matusov is a Professor of Education at the University of Delaware. He was born in the Soviet Union and studied developmental psychology with Soviet researchers working in the Vygotskian paradigm. He worked as a schoolteacher before immigrating to the United States. He uses sociocultural and Bakhtinian dialogic approaches to education. Address for correspondence: School of Education, University of Delaware, Newark, DE 19716, USA (ematusov@udel.edu).

\section{Acknowledgments}

I am very thankful to Jim Rietmulder, Ana Marjanovic-Shane, Kathy von Duyke, Nermine Abd Elkader, Scott Richardson, Robert Hampel, Alexander Sidorkin, and Bryan Campbell for providing constructive criticism, raising important questions and concerns, making fruitful suggestions, discussing issues, and providing editing on earlier versions of this paper.

038080 


\section{Legitimacy of non-negotiable imposition in diverse approaches to education}

Modern organized education can be at times very exciting for some students but, for many others, it also can be felt as very oppressive, alienating, punitive, if not merely violent - psychologically, relationally, or even physically. This article is aimed on investigation of the latter relational aspect of organized education. The etymology of the majority of educational terms in diverse languages often refers to some level of (violent) imposition, whereby a teacher imposes on a student something that the student may not wish to do on his or her own. "[T] he root of the [Hebrew] word for teach/learn (דמל) coincided with that for the goad, specifically the one used to prod cattle" (Moore, 2009, p. 422). Modern conventional education is full of impositions on its students - such as what, how, and where students do, learn, behave, attend, participate, and communicate in the ways that the teacher and school define. For certain ages of students, schooling itself is compulsory in modern societies and, thus, imposed. However, the legitimacy of this imposition - how much of this imposition is necessary, useful, justified, and desirable for education itself - has not been specifically discussed and analyzed yet. This is especially important to do for innovative education, evaluating and reconsidering its goals and practices of education. I believe that analysis of imposition in education can help to address important questions of why oppression, alienation, if not pedagogical violence, are so prevalent in organized education and whether they is can be avoided or not.

So far, I could not find an existing satisfactory theoretical framework for impositions in education by looking in the work on the power relations in Marx, Foucault, Bourdieu, Arendt, Mouffe, and other political scholars. That is why I had to sketch my own theoretical framework that I developed based on my analysis of diverse educational practices that I discuss in this paper. My theoretical framework is rather empirical as it was inspired (but not followed) by Grounded Theory methodology (Glaser \& Strauss, 1967). The described emergent patterns are informed by particular practices rather than philosophical consideration and do not have "the over-arching typology." I see the validity of my patterns not in some "good method" of study but in usefulness of them for other scholars and educators (including myself) and in a potentially emerging follow-up critical dialogue. Considering how my emergent empirical theoretical framework relates to the existing theories of power can be an interesting endeavor but it is outside of the scope of this paper.

Imposition is an inherent part of social relations and communication. We constantly impose on each other when we talk to, act with, and relate with each other. People and life itself, - through its necessities and exposures, - constantly impose on an individual, contrasting with the individual's selfinitiated and self-generated activities and spontaneous actions. Impositions of other people's desires and their lives on us constitute the very fabric of our relations with others. When accepted, legitimate, or negotiable impositions diminish and shrink, our relationship usually weakens and shrinks - to be in a relationship means to impose on each other legitimately ${ }^{2}$. We often say and do something that another person does not necessary expect or want us to say and do. We impose responses on other people. For example, by writing this text, I am imposing my ideas, themes, foci, reading on my readers. However, this type of imposition is arguably very different from the one used so often in conventional education. An everyday imposition is usually negotiable, while an imposition in conventional institutionalized education is not. In an everyday imposition, it is often legitimate for an addressee to negotiate, redefine, or even reject a bid for an action or a response, imposed on the addressee by the addressor. Thus, using my example above, my readers (e.g., you) may legitimately interpret my ideas in their own ways, disagree

\footnotetext{
${ }^{1}$ Elsewhere I argue against positivistic notion of "research methodology" - an idea that some kind of research methods pre-exist research (i.e., given) - in favor of "research antimethodology" and "research mastery" - a unique, authorial, and contextual way of doing a particular research that fully emerges when research is completed (Matusov \& Brobst, 2013, pp. 119-132).

${ }^{2}$ A dear friend of mine often started her address to me, "Sorry to bother you but..." My reply to her was, "Friends are those who can freely bother each other. When you stop bothering me, our friendship will end. Please keep bothering me...."
} 
with them, change them, reject them, reply to them, praise them, adopt them, or even stop reading the text altogether and move to do something else.

In contrast, in conventional schools, this negotiation of imposition is usually illegitimate: students often must do exactly what the teacher and school demands them to do with the teacher, who also judges the success of the students' actions in response to the imposition. Of course, both negotiable and nonnegotiable impositions occur in and out of schools. To be exact, in our everyday life, outside of schooling, we have been experiencing both types of imposition - negotiable and non-negotiable - but mostly negotiable impositions (unless, for example, one serves in the military or the police force). Similarly, legitimate negotiable imposition happens in conventional schools as well - students can ask questions or permission or even initiate their own activity - but usually it occurs outside or on periphery of the official classroom time, space, and activity. Students' active attempts to negotiate or reject the teacher's impositions are often viewed as illegitimate disruptions of teaching-learning processes. Conventional schooling is defined by extensive and predominate use of non-negotiable imposition while this may not necessarily be true for life outside of school.

Non-negotiable imposition in education can be immediate, when the person imposing is present and in a direct face-to-face contact with the student. It also can be mediated, when the person or institution imposing is not immediately present and not in direct contact with the student. An example of mediated imposition is a Kaplan test prep class where the instructors coach the students who chose to attend in order to do well on an external exam like GRE. The latter example makes it necessary to consider the legitimacy of non-negotiable imposition in education. Thus, I consider the non-negotiable imposition (immediate or mediated) to be legitimate when it is accepted by the students. I want to clarify that in this paper, I discuss and consider the very legitimacy of diverse non-negotiable imposition approaches in education.

My goal of the paper is to consider different approaches to non-negotiable imposition in education, its legitimacy, and justifications and analyze their pros and cons as I abstract them from these practices and espoused theories by the educators involved in these educational practices. Studying education, I have abstracted the following distinct major educational practices and their approaches to non-negotiable impositions: Totalizing conventional, Capitalist, Progressive, Democratic, Anarchist, and Communitarian educational approaches to imposition. Currently, I remain agnostic about whether some non-negotiable impositions can be good (i.e., legitimate) or not in general, but currently l'm leaning toward a point that some of them may be good under some conditions.

\section{Pros and cons of non-negotiable imposition in education}

Although conventional educators embraced non-negotiable imposition in education, many innovative educators often remain uneasy and indecisive (if not contradictory) on this issue. In her dissertation studying innovative schools, von Duyke considered these uneasy attitudes toward impositions by innovative educators,

\footnotetext{
For example, Morrison (2007) writes about her experiences in what she describes as a progressive free school in Albany, New York. She and the school staff seem to vacillate in terms of imposing curriculum or not on students. On the one hand there is the idea of not imposing a standard curriculum on students so they can follow their learning interests path; on the other hand, teachers often push academic subjects to ensure students' ability at meaning making through developing the resource of broad areas of knowledge. On the one hand, there is a concern that students have autonomy; on the other hand, that they should be pushed into particular learning. Below are some passages from the same book explaining the philosophy of the school, and I have highlighted several passages that either suggest that a teaching curriculum should not be imposed, or then suggest that some teaching curriculum should be imposed:
}

Dialogic Pedagogy: An International Online Journal | http://dpj.pitt.edu DOI: 10.5195/dpj.2015.110 | Vol. 3 (2015) 


\section{Legitimacy of non-negotiable imposition in diverse approaches to education}

Eugene Matusov

\section{Curriculum should not be imposed.}

Teachers at the Free School are not burdened by having to impose a curriculum on the students and students are not burdened with the expectation of unquestioningly accepting what is imposed on them (p. 117).

Teachers see a student show a spark of interest in something and from that encourage the child ( $p$. 131).

The progressive teacher, in that she has no set body of knowledge to transmit, is not interested in the students' "performance" regarding knowledge retention; rather the teacher is more interested in the process of meaning making, which in her mind signifies growth and change (p. 117).

Thinking critically means imposing critical dialogue and specific learning on students.

But Free School teachers also recognize that some kids need more than gentle prodding-that, in fact, they require a push (p. 133).

As I mentioned previously, critical consciousness involves not just being able to question and challenge, but also having the skills to negotiate in the world. By being available to student requests for academic teaching and gently prodding the students to develop their academic skills, the teachers are explicitly working to develop in students another aspect of critical consciousness (p. 94).

The teachers knew full well that this pushing violated, in many ways, the Free School's core philosophy, but they also felt that not to do something would harm these particular children's quest for meaning (p. 134) (von Duyke, 2013, pp. 18-19).

It is reasonable to assume that there should be reasons for extensive use of non-negotiable imposition in education, in contrast to everyday life. Non-negotiable imposition seems attractive for conventional schools. But why? What are benefits of non-negotiable imposition for education?

A big attractor of using non-negotiable imposition for many educators (and general public) is that it seems to engage ALL students in important learning activities on a systematic basis - despite the fact that students may not choose and wish to be engaged in these learning activities on their own. One of these educators' major rationales is that the importance of the learning experiences resulting from the imposed engagement in these learning activities could be appreciated by the students later on, when the students may need to use the skills and knowledge learned in school. Thus, although students may not use calculus in their everyday lives, some of them may find it useful when they become, for example, mechanical engineers. When the (social) life necessity for calculus emerges, the student will be ready to meet this challenge, thanks to the non-negotiable imposition of important learning activities designed in school.

Another reason for non-negotiable impositions is exposure and serendipity: sometimes being forcefully exposed and thrown in new experiences and activities, students may start liking them, which might not necessarily happen without this non-negotiable imposition. For instance, some students may find themselves liking history through history being imposed on these students in the first place in school. Not being forcefully exposed to potentially exciting activities, in which a student might engage on his or her own, may rob the students from future (economic) opportunities, social mobility, self-actualization, and a more fulfilling life. Similarly, non-negotiable imposition can promote serendipity - an exposure to certain experiences on the periphery of required learning activities that students may find attractive. Without being engaged in a vast amount of required learning activities, this exposure might have been unlikely for many students. For example, when I asked a few graduate students of mine to give an example of their highly engaged learning that they did beyond required, they gave examples of such engagement stemming from assignments non-negotiably imposed by their professors,

You [i.e., me - EM] write, "Where is in your actions, 'I want to be a researcher'? I mean beyond survival...

Beyond professors asking you to do stuff for the classes... What is the evidence, colleague?"

Dialogic Pedagogy: An International Online Journal | http://dpj.pitt.edu

DOI: 10.5195/dpj.2015.110 | Vol. 3 (2015) 


\section{Legitimacy of non-negotiable imposition in diverse approaches to education}

Eugene Matusov

The evidence is that I have locked myself away for over a week now working on putting together research that I have been collecting over the whole semester on issues that I feel passionate about. Yes, this started as an assignment for Rita's [another professor] class, but it's not anymore. It's my own work. I am bending her class rules, including by handing it in later than she wanted the rough draft because I still feel the need and desire to work on it more, you see, because I am not working on it for her, but I am working on it for me! This work is helping me shape what it is that I want to research for my thesis and how. And, although I'm over busting my ass, and I may be pissing her off as the instructor, I don't care because it's worth it for my own learning and for me following my passion! In addition, I am giving up social activities and what non-academics would call "life" because I care about this research so much. I'm sorry that it doesn't perfectly align with your research interest in dialogic pedagogy, but I do think that it is related, and I am going to explore the connection between my research interest and dialogic pedagogy in my final project for you - by my own choice. I could have not cared and done some BS final project just to turn in, but I can't and I won't because my interest and passion and life's work (so far) in ed research means too much to me (Matusov \& Brobst, 2013, p. 97).

Non-negotiable imposition in education can be also helpful for creating synchronization, coordination, and sharedness of learning experiences and, thus, a collective focus among the students so necessary for certain learning activities such as a classroom or online discussion, lecture, and cooperative learning. Without the establishment of a shared collective focus a collective investigation or study of learning material becomes difficult if not impossible at times. Although such a shared collective focus can emerge on negotiable and/or volunteer and/or self-initiated basis, it is not guaranteed on a systematic and predictable basis across all students, all the time, across all learning activities.

From a long-run perspective, non-negotiable imposition in education feels attractive because it creates strong societal centripetal forces (Bakhtin, 1991) by promising shared learning experiences across all citizens of the society and, thus, by increasing societal cohesion and reducing its fragmentation (Hirsch, 1996). Sidorkin (2009) argues that standardization, which I insist is based on educational nonnegotiable imposition, is responsible for the phenomenon of culture because without educational nonnegotiable imposition, reproduction of culture is impossible. He argues "the only way to understand curriculum [of organized, institutionalized, education], is to separate it from naturally occurring student interest. There is simply no point in educating otherwise" (personal communication, January 2013). Educational non-negotiable imposition forces a new generation to acquire achievements of the past generations whether the new generation wants them or not. And by that creates continuity of passing down the values and allegiances to the family, the group, the party, the mainstream institutions, the mainstream practices, the nation, and the leaders of these groups (parents, local and national "education tsars" or officials, etc.). It also promises creation of an all- and well-rounded person, a "Renaissance man," who is equipped with affluent "cultural capital" (Bourdieu, 1990) that can empower a person's economic, political, institutional, intellectual, aesthetic, and so on, life (Hirsch, Trefil, \& Kett, 1988).

Finally, non-negotiable imposition in education can create conditions for easily measured accountability for the students' learning and teachers' teaching by measuring how poorly and how well students succeed in complying with non-negotiable impositions and how reliably teachers impose them. Standardized and non-standardized educational tests, quizzes, exams, and questions with well-defined pre-known answers seem to serve well for this purpose. The universality of non-negotiable imposition in education creates a sense of fairness, non-arbitrariness, objectivity, and meritocracy. It makes it easier to tokenize education into credentials (e.g., diplomas, certificates, degrees, grades, GPAs, test scores) that can be easily compared and exchanged for qualifications, professions, jobs, salaries, permits, licenses, and promotions solely or in addition to other forms of assessment. These credentials become not only the best available proxy for competence but also for trainability. Although a novice with valid educational credentials may lack a necessary experience or even competence required by a particular job, it is 


\section{Legitimacy of non-negotiable imposition in diverse approaches to education}

Eugene Matusov

assumed (but usually not tested!) that this novice would learn the targeted practice faster, easier, and better than a similar person without these educational credentials (Labaree, 2010).

However, non-negotiable imposition in education also apparently creates its own problems. It can suppress and discourage students' negotiation, rejection, and activism - i.e., students' meaningful active learning - by making it illegitimate. Students' attempts to negotiate or reject the teacher's non-negotiable impositions, bring their own self-initiated activities, and/or introduce their own impositions on the teacher and/or other students are often viewed by the teacher as aggressive challenges, disrespectful disruptions, unprovoked resistance, immature acting out, wasteful "off-tasks", irresponsible laziness, and unwelcomed "off-scripts" (Kennedy, 2005). For at least 12, if not 16, of their most formative years, many students must spend most of the 5 days in a week being socialized in activities designed, defined, constrained, imposed, and judged by other people, unilaterally, at expense of their own activism, collaboration, and negotiation with others ${ }^{3}$. Non-negotiable imposition in education apparently discourages, if not robs, students from guided and emergent development of their learning, personal, and social activism, collaboration, negotiation, agency, creativity, individualization, autonomy (i.e., just say "no" to impositions by others), goal-defining, value-defining, and self-actualization. Grades, rewards, punishments, and power hierarchies promote conformity to the teachers' and societal unconditional demands and diminish possibilities for critical thinking (Kamii, 1991; Kohn, 2014; Trevino, 2004).

As a result, non-negotiable imposition in education often feels oppressive and tiresome. It creates conditions for students' resistance and teacher's pedagogical violence - i.e., designing and enacting physical, emotional, institutional, relational, and symbolic pains for students to make them comply with the teachers' non-negotiable educational impositions or to punish for non-compliance. It has a huge potential for creating vicious circles of distrust, aggression, and violence between the teacher and the students and among the students. It distracts students from learning and teachers from teaching by draining a lot of teachers' and students' energy and attention on enforcing and resisting the impositions, surveillance on the students' actions and behavior, the system of rewards and punishments, and maintenance of the unilateral social order (see critique of the oppressive nature of conventional education in Holt, 1972; Jackson, 1968; McLaren, 1993; Sidorkin, 2002; Waller, 1932; Willis, 1981). Arguably, rather than academic curriculum, the non-negotiable imposition of conventional schools is its hidden and major curriculum. As Farber (1970) wrote in a long text worth quoiting in its entirety,

\footnotetext{
The medium in school truly is the message ${ }^{4}$. And the medium is, above all, coercive. You're forced to attend. The subjects are required. You have to do homework. You must observe school rules. And throughout, you're bullied into docility and submissiveness. Even modern liberal refinements don't really help. So you're called an underachiever instead of a dummy. So they send you to a counselor instead of beating you. It's still not your choice to be there. They may pad the handcuffs - but the handcuffs stay on.

Which particular subject they happen to teach is far less important than the fact that it is required. We don't learn that much subject matter in school anyway in proportion to the huge part of our lives that we spend there. But what we do learn very well, thanks to the method, is to accept choices that have been made for us. Which rule they make you follow is less important than the fact that there are rules. I hear about English teachers who won't allow their students to begin a sentence with "and." Or about high schools where the male students are not permitted to wear a T- shirt unless it has a pocket. I no longer dismiss such rules as merely pointless. The very point to such rules is their pointlessness.

It's how you're taught that does the harm. You may only study geometry for a semester - or French for two years. But doing what you're told, whether or not it makes sense, is a lesson you get every blessed
}

\footnotetext{
${ }^{3}$ For some US middle class children, this non-negotiable imposition may be extended to afterschool extracurricular activities imposed by their parents (Lareau, 2003).

${ }^{4}$ This seems to be a paraphrase of the famous quote "The medium is the message" from Marshall McLuhan and his theory of media from the book "Understanding media the extensions of man", 1950.
} 


\section{Legitimacy of non-negotiable imposition in diverse approaches to education}

Eugene Matusov

school day for twelve years or more. You know how malleable we humans are. And you know what good learners we are-how little time it takes us to learn to drive a car or a plane or to play passable guitar. So imagine what the effect must be upon our apt and impressionable minds of a twelve-year course in servility. Think about it. Twelve years of tardy bells and hall passes; of graded homework, graded tests, graded conduct; of report cards, GPA's, honors lists, citizenship ratings; of dress codes, straight lines and silence. What is it that they're teaching you? Twelve years pitted against your classmates in a daily Roman circus. The game is Doing What You're Told. The winners get gold stars, affection, envy; they get A's and E's, honors, awards and college scholarships. The losers get humiliation and degradation. The fear of losing the game is a great fear: it's the fear of swats, of the principal's office, and above all the fear of failing. What if you fail and have to watch your friends move past you to glory? And, of course, the worst could happen: you could be expelled. Not that very many kids get swats or fail or are expelled. But it doesn't take many for the message to get across. These few heavy losers are like severed heads displayed at the city gates to keep the populace in line.

And, to make it worse, all of this pressure is augmented by those countless parents who are ego freaks and competition heads and who forcibly pass their addiction on to their kids. The pressure at school isn't enough; they pay the kids for A's and punish them for D's and F's.

But can you feel any of this? Can you understand what has been done to your mind? We get so used to the pressure that we scarcely are conscious of it without making some effort ${ }^{5}$ (Farber, 1970, pp. 20-21).

The following famous saying may be not completely inaccurate as applied to non-negotiable imposition in education, "you can take the horse to the river, but you can't force it to drink." Conventional teachers can manage to make some students learn academic subjects, although the quality, depth, personal meaningfulness, and longevity of such learning remain questionable. Since learning is an essentially agentive process (Matusov, 2011), requiring students' efforts, goals, desires, and subjectivity, non-negotiable imposition in education makes learning difficult and shallow while teaching becomes blind, coercive, and ineffective. Despite its promises, non-negotiable imposition in education rarely, if ever, can deliver the development of all- and well-rounded persons, the defragmentation of society, and universal personal empowerment. The existence of non-negotiable imposition raises questions of how much things like: well-rounded person, defragmentation of society, and universal personal empowerment are possible or even desirable in education or even by themselves. Specialization, exclusion, and particularity may be more realistic and more desirable educational and societal aspirations.

Another big, but related, problem with non-negotiable imposition in education is that it makes educational practices not self-correcting and, thus, hugely ineffective. When the teaching curriculum, the guidance, the organization of the classroom environment and the activities are all insensitive to a student, the results often are the student losing attention, interest, and engagement. In the absence of selfcorrecting loop, the teacher focuses usually on making the student comply with the teacher's demands and expectations rather than on making the teaching curriculum and instruction more sensitive, relevant, and meaningful for the student's educational needs, well-being, and interests. Instead of focusing on how to become a better educator, the teacher often focuses on how to become a better police(wo)man, blaming the students for non-cooperation. In this case, the teacher does not treat signs of breakdowns in the teacher-student relation as a sign, calling for improvement of his or her pedagogy and the overall ecology of the classroom to make it more livable for the students, but rather as a sign of the students' offensiveness. Imagine a movie director who focuses on how to more efficiently discipline an audience bored with his or her movie, rather than considering the movie to be a flop and focus on the improvements in the future movies (or leaving the profession or finding a more suitable audience)?! But

\footnotetext{
5 "...not only that but our minds are colonized in such a way that we don't believe that there is a better way. One of my [undergraduate, education major] students, in her criticism of Summerhill, said, 'But you need to prepare the kids for authority in the workplace.' She said and others in the class agreed, 'Imagine how those kids will treat their boss or even worse imagine how they will treat their employees'” (Nermine Abd Elkader, personal communication, 2012-11-19).
} 
this is exactly what many conventional teachers, who use exclusively non-negotiable imposition in education, do. Instead of reliance on a self-correcting process, as it is done in many practices, conventional schooling, based on non-negotiable imposition, relies excessively on accountability to promote its quality, which, arguably often is counter-productive in education.

Accountability creates additional problems for education in its own way. Accountability is based on summative assessments necessary for evaluating the effectiveness of the non-negotiable imposition in education. Summative assessments sort students to the institutionally "successful" and "failing" and, thus, distract students from their genuine learning. Instead of focusing on genuine learning, the students focus on how to guess correctly what school wants from them and how to conform successfully to these arbitrary requirements. Institutional failure promoted by summative assessments in education nonnegotiably imposes the deficit model (Rogoff, 2003) on the "failing" students. Meanwhile, institutional success based on summative assessment replaces genuine learning with conformity to the authority for the "successful" students. When a student-initiated negotiation enters into such a regime of nonnegotiable imposition, it is often a negotiation about a grade, not about learning (Diederich \& Hampel, 2014; Kohn, 2014).

Summative assessments disrupt the trust between the teacher and the student necessary for promoting sensitive guidance. Indeed, for a teacher to guide sensitively, the teacher must access the students' subjectivities - how they perceive the world and particular curricular issue at hand, what they think and why, and so on. However, in the context of summative assessments and accountability, it can be very costly for a student to reveal his or her own subjectivity, which can involve mistakes, ignorance, and misconceptions. The teacher and the students often become involved in a "double bind": on the one hand, the teacher invites the students to reveal how they think and feel and act to make his or her guidance sensitive but on the other hand, the students must meet the teacher's non-negotiable expectations and demands to avoid the teacher's punishments. For a student to play safe often means to become silent, passive, and/or conformist.

Arguably, non-negotiable imposition in education is anti-educational in principle, although this may not necessarily be revealed in each and every particular application of non-negotiable imposition. Non-negotiable imposition can establish an authoritarian (if not totalitarian) regime of truth because by definition of being non-negotiable, it does not invite independent evaluation of the imposition by the students (although the students still may engage in such evaluation). Truth is something that the teacher, the textbook, and the test tell the student to be true. The students are not free and autonomous agents and participants in the establishment and judgment of truth. As Bakhtin argued, schooling based on nonnegotiable imposition promotes excessive monologism and "authoritarian discourse" establishing truth through the institutional authority of the teacher, textbook, tests, and exams rather than through the testing of ideas, considering alternatives, raising genuine questions of the students' interests, pursuing their own and each other's inquiries, and critical examination of underlining values and assumptions (i.e., "internally persuasive discourse") (Bakhtin, 1991; Matusov, 2007, 2009; Matusov \& von Duyke, 2010; Morson, 2004). Bakhtin wrote,

\footnotetext{
In an environment of ... monologism the genuine interaction of consciousness is impossible and thus genuine dialogue is impossible as well. In essence ... [excessive monologism - EM] knows only a single mode of cognitive interaction among consciousnesses: someone who knows and possesses the truth instructs someone who is ignorant of it and in error; that is, it is the interaction of a teacher and a pupil, which, it follows, can be only a pedagogical dialogue (Bakhtin, 1999, p. 81).
}

Finally, compliance to the teachers' non-negotiable imposition and focusing on obtaining credentials distracts students from their own agency as learners, from ownership of the students' own lives 
(Rietmulder, personal communication, December 2012), from their own emergent interests, inquires, needs, and questions, from their own desires to learn and seek help for learning. The biggest hidden curriculum in conventional schools is often for the student to find a pattern of his or her own actions that lead to the teacher's approval and success on the test. Test-taking is a practice in itself, requiring its own mastery and learning, independent of academic learning. Paradoxically, the deeper one learns and takes tests' questions and problems seriously, the worse one does on a test as he or she transcends limited truths expected by the test designers and evaluators. Similarly, one does not need to genuinely engage in academic learning to pass tests (Gee, 1996).

Taking together all these pros and cons of non-negotiable imposition in education, I remain ambivalent about its legitimacy seeing both its potential usefulness, if not necessity, but also its potential damage, if not oppression. In the next section, I consider seven diverse approaches to non-negotiable imposition in education that I have extracted from current educational practices and literature. I examine how they address the PROs and CONs listed above, and discuss their strengths and limitations. I specifically focus on the legitimacy of non-negotiable impositions within each approach: how it justifies it, addresses its CONs, and limits itself.

I gave political labels to the educational approaches to describe them, which can be both revealing and misleading. It can be revealing because the issue of legitimacy of non-negotiable imposition is the issue of power and, thus, politics (Kukathas, 2003). Political labels can capture the nature of power relations within each approach. However, conventional political labels are polysemic and loaded with rich connotations - they can be misleading for the readers by promoting value-judgment associations with specific political regimes that I may have not intended. In my use of the political terms, I am coming not from conventional politics concerned with the question of "good society" (Kukathas, 2003) but from educational politics concerned with the question of "good education." Although a conventional (purely) political approach may also be concerned with education, its concern about education is usually subordinated to the concern about a good society. In contrast, in an educational approach, the concern about good education is primary ${ }^{6}$. For example, a Political Anarchist approach may prioritize "social justice" or "tolerance to diversity" as his/her particular way of defining good society (Kukathas, 2003) and develop a Political Anarchist approach to education - envisioning education that help to arrive at his/her vision of good society (e.g., Ferrer Guardia, 1972; Suissa, 2010). Political Anarchists subordinate the goal of education to embetterment of the society (in their own vision of this embetterment) and, thus, treat education mainly instrumentally. In contrast, an Educational Anarchist approach (see below) uses some Anarchist principles in defining a good education without necessary being concerned about a "good society" and does not subordinate the goal of educational practice to embetterment of the society ${ }^{7}$. I hope my discussion creates its own counter-connotations making misleading associations less likely (but never impossible).

\footnotetext{
${ }^{6}$ My colleague and a scholar of Libertarian approaches to education Kevin Currie-Knight describes the tension between Political and Educational Approaches based on similar power relations in the following way in his response to this paper, "Educational libertarians (John Holt, William Godwin, Ivan Illich) want education to be free from authoritarianism, regardless of whether government is involved (even though government involvement makes it SIGNIFICANTLY less likely that education won't be used for subservience purposes; it is no mistake that the three figures I mentioned are both educational libertarians and political anarchists). Political and economic libertarians ([Ayn - EM] Rand, Frank Chodorov, Milton Friedman) seek to give families more educational choice and reduce government's role in education, even if that means allowing parents more freedom to choose authoritarian kinds of schooling for their children" (personal communication, November 2012). However, there can be also an overlap between these approaches, hybridization, and even application of both of them (like, for example, in Plato's writings). In some cases, the boundary between them can be very fuzzy.

${ }^{7}$ Although some educationalists, such as, for example, Ira Shor and Ivan Illich, who argue and/or practice an Educational Anarchist approach, are apparently also concerned about good society.
} 


\section{Legitimacy of non-negotiable imposition in diverse approaches to education}

Eugene Matusov

\section{Approaches to non-negotiable imposition in education}

Totalizing approach of conventional schooling

Non-negotiable imposition is usually comprehensive and totalizing for the students within conventional schools. I call this approach "totalizing" because it tries to eliminate or minimize any negotiation with the students about educational processes and their organization. Elsewhere, I have defined it as "the Assignment Chronotope" (Matusov, 2009, 2015; Matusov \& Brobst, 2013), a pedagogical design in which physical and didactic space, time, communication, movements, and the system of values are organized by the teacher and the school through unconditional and non-negotiable assignments and demands. The teacher imposes education on the students: when to learn, what to learn, what is important, how to learn, what and how to do, when and how to move, when and how to talk, what to focus on, and so on. Negotiation with students about these impositions is rarely considered to be legitimate or welcome. My point here is that conventional schools heavily embrace the totality of nonnegotiable impositions in education. Saying all that, l'd also argue that, on average, in the middle-class suburban conventional schools this totality seems to be much softer than, in urban working conventional class schools.

The primary legitimacy of this totalizing non-negotiable imposition seems to be rooted in the epistemological authority of the teacher as the Expert\#1 and, through the teacher ${ }^{8}$ (and/or school, government, business), in the entire society. It is assumed by many conventional schools' participants and proponents that the teacher, the school, government, and society know better (if not the best) what is good for the student with regard to his or her education and how it is organized. Since the student is often seen as ignorant, immature, and somewhat irresponsible, the student's input into his or her own education is also viewed as counterproductive, distractive, and irresponsible.

The second justification for the legitimacy of this totalizing non-negotiable imposition seems to be rooted in the societal needs for its own reproduction and development, as the entire society apparently needs skillful, well-informed, capable, and knowledgeable citizens of democracy, workers of economy, and clients of diverse institutions and bureaucracies (cf. the educational goal of "social effienciency", see Labaree, 1997). Arguably, education can help to achieve these important societal goals. Since students are usually either non-participants or very peripheral participants in democracy, economy, institutions, and bureaucracies, they also are not allowed to decide or engage in negotiation about their own education. Finally, since public education is funded mostly ${ }^{9}$ through Federal, State, and Local public money by taxpayers, it is assumed that the state, representing the taxpayers, has the legitimacy to dictate the goals, curricula, and instruction in at least public schools (cf. the saying, "he who pays the piper calls the tune").

However, these justifications of the legitimacy of the totalizing non-negotiable imposition in education seem problematic to me for several reasons. First, education is a future-oriented practice but the future is essentially unknown. Conventional education extrapolates the future based on the somewhat known past and present, which in a rapidly changing and change-accelerating society apparently becomes very inaccurate already by the time of the student's graduation from K-12 school but especially through the alumni's life-time that is supposed to be targeted by the school education. For example, I remember how in the early 1980s the programming language BASIC was associated with "computer literacy" and was considered as the absolute-must part of the school mandated curriculum (e.g., see Linn, 1985). BASIC became obsolete by the end of the 1980s. Thus, in the contrast to arguably wasteful and

\footnotetext{
${ }^{8}$ Often a teacher can be a slavish token representative of other power sources, having very little freedom or flexibility of the curriculum and/or instruction and/or social relations with the students.

${ }^{9}$ Since affluent middle and upper class parents may heavily contribute financially and otherwise in education of the children attending public schools directly by giving extra money to schools through, for example, PTA or indirectly by buying educational opportunities only to their own children, it is not clear if taxpayers money always constitute the biggest share of financial burden of public education for these students. More research is needed.
} 
counterproductive education rooted in the known past and present, the education-for-unknown-future should be based on promoting the student's agency in the student's present as a process of the constant transforming the present into the future. In such innovative pedagogical approach, rather than being passive and disinterested in the acquisition of the ready-made past, the students would actively and creatively engage in learning about the past through transformation of this past into the present (and the future) to address their own current needs, inquiries, and interests. However, development of the student's agency, requiring student's self-generated authorship, creativity, and initiation of new activities of the student's own interests and needs, is rather problematic in the regime of the totalizing nonnegotiable imposition by the teacher, school, government, businesses, and the entire society.

Second, it is rather questionable to limit and reduce education to the students' acceptance and mastery of the status quo as conventional schools seem to imply through their pedagogical practices of totalizing non-negotiable imposition. What seems to be necessary to fulfill the educational promise to make the students informed and empowered in reaching their own decisions rather than just being socialized into the status quo, is, in fact, students' own critical examination of the existing practices and their underlining values, with and without teacher's assistance, e.g. learning and considering known limitations, objections, and alternatives to the practices and their values, and engaging in collective and personal testing ideas. The tension among the competing definitions of education - 1) alienated training, 2) participatory socialization in the socially valuable practices, and 3) critical dialogic evaluation of the existing practices and their transcendence (Matusov \& Marjanovic-Shane, 2012) - challenges the legitimacy of the totalizing non-negotiable imposition in education common to conventional schools. Students' engagement in participatory socialization in the existing practices and, especially, in critical dialogue about these practices requires negotiation of impositions, students' (co)authorship in shaping educational practices, and students' activism about their own education. Even more, from a position of a critical dialogue as the major goal of education, the very deciding what is good for the students, including inquiry into what kind of education is good for the students, is arguably a part of critical education in itself. By excluding students from decisions about their education, the teacher, school, government, businesses, and the society arguably rob the students from genuine education.

Third, it seems to be paradoxically strange and politically suspicious to insist on students' socialization in a totalitarian institution of school based predominately on non-negotiable imposition, for 12-16, if not more, of the students' most formative years, all in the name of the students' preparation for their future participation in a liberal democracy and capitalist economy based on active decision making and making smart and responsible choices. Why cannot liberal democracy, active decision making, and making smart choices reproduce itself without the crutches of educational totalitarianism?! Doesn't dependency on educational totalitarianism undermine liberal democracy and the capitalist economy?! Doesn't totalitarian non-negotiable imposition of conventional schooling, where the teacher, textbook, or test is the last word of the institutionally recognized truth, hijack the educational goal of making students informed by making the students brainwashed (cf. characterization of mainstream conventional schools as "civic church", Collins \& Halverson, 2009)?!

\section{Capitalist approach by Sidorkin ${ }^{10}$}

Although an educational philosopher, Alexander Sidorkin apparently accepts the societal legitimacy for a totalizing non-negotiable imposition of the academic curriculum in education, he at the same time rejects:

1) conventional schools' focus on teaching as the main factor ensuring the quality of education,

\footnotetext{
${ }^{10}$ The term "capitalist approach" in the reference to Sidorkin's educational approach is mine. It is aimed at capturing his approach to educational non-negotiable impositions and not other important aspects of his very interesting and thought-provoking educational analysis and suggestions. He read a previous draft of this paper and did not seem to object my term or portrayal of his position.
} 


\section{Legitimacy of non-negotiable imposition in diverse approaches to education}

Eugene Matusov

2) reliance of conventional schools on pedagogical violence as the backbone of the totalizing nonnegotiable imposition, and

3) misleading and counterproductive ideology of conventional schooling that the education is primarily for the students', rather than for the society's benefit (Sidorkin, 2002, 2009).

Sidorkin argues that although the teacher's instruction can facilitate learning, it is not its primary engine. Rather, the main engine of learning are the student's own studies - their extent, intensity, depth, and quality, - assisted or unassisted by the teacher. In conventional schools, students' studies are shaped by the totalizing non-negotiable imposition, which is fine with Sidorkin. What is not fine is the fact that these totalizing non-negotiable impositions are enforced by pedagogical violence and justified by a misleading idea that education is done to primarily benefit the students themselves. He continues that many students intuitively recognize that this ideology is misleading and not true, viewing their academic studies in conventional school as work that they have to do for their teachers and not for themselves. Sidorkin insists that the society must recognize and admit that institutionalized education primarily exists for the good of the society and not for the sake of the students. Like any consumer of its value-use produced by others, the society must pay to students their education. He argues that if this were true, most of students (but probably not all) would willingly surrender to the totalizing non-negotiable curricular impositions by teachers, schools, and society. Neither mandatory school attendance nor pedagogical violence would be necessary. Thus, Sidorkin concludes, the students should be compensated for their labor of academic studies, as desired by the society (not necessarily by the students).

He proposes two types of such compensation. The first type of compensation is what my colleague and I called "exchange of favors" (Smith \& Matusov, 2010). Sidorkin models it after sports coaching. Coaches often ask student athletes to do unpleasant practice - i.e., non-negotiable imposition - but in exchange the coaches provide extracurricular friendship socialization and social mentoring, important for the student athletes. What is negotiable in this approach is what "compensation" in a form of desired socialization the athletes would get in return for the coach's non-negotiable imposition of unpleasant and harsh drills and practices on them. Sidorkin argues that some good teachers know that and do it as well and that all teachers should do the same. Also, to some degree, his model of the "exchange of favors" already exists for many middle-class US children in form of extracurricular and afterschool activities and clubs, in which students have more choice, voice, and negotiation. Some of these activities are conditional on the students' cooperation with non-negotiable impositions of school and some of these activities are even run or facilitated by the same teachers (Eckert, 1989; Lareau, 2003; Powell, Farrar, \& Cohen, 1985).

Sidorkin's second way of compensation is monetary ${ }^{11}$. Like in a capitalist economy, if one party needs some alienated labor from the other party, the first party must pay for the labor as defined by the regulated market economy. The pay has to be determined by the exams measuring learning and set by the society. It is up to the students how they want to study for the exams with or without teachers. If students choose to study by themselves, they would have to work probably harder but they would get more compensation as they do not need to share it with their teachers. Alternatively, the students may hire teachers either on an individual basis as their personal tutors (which would be probably more expensive) or on a shared basis by attending schools for which they would pay teachers. Sidorkin estimates that the total price tag of this educational compensation paid by the society to the students (or

\footnotetext{
11 "It is very interesting to see that Sidorkin's capitalist view of education is actually applied in Egyptian public higher education. University students who are higher achievers are paid a monthly stipend to compensate them for their hard work. It is also noteworthy that this stipend is not restricted to top students but to anyone who achieves an $80 \%$ on their GPA throughout their University education career (and since public education is free, this stipend is considered to be making money since it is totally up to the students to use however they wish)" (Nermine Abd Elkader, personal communication, 2012-11-19). Also see the NYC CEO program's efforts to monetary incentivize low income students and their families for academic achievements (http://www.mdrc.org/preliminary-look-early-educational-results-opportunity-nyc-\%E2\%80\%93-family-rewards-program).
} 
their guardians for very young students) should be less than currently the society spends on public education.

I labeled this approach as "capitalist" because like in a capitalist economy, alienated labor is compensated rather than forced through violence or a threat of violence as it is done in slavery or feudalism - this economic analysis of social relations in education was introduced by Sidorkin himself (Sidorkin, 2002). Under the capitalist system, labor mainly remains alienated and non-negotiable to please other people (i.e., employer, customers) but compensation for and participation in this labor is negotiable. Like in the totalitarian approach described above, student's learning and study remain alienated from the student's own interests, needs, inquiries, and so on. However, students are viewed as free, contractual, laborers in a free supply-demand labor market with a societal demand for the students to study. Essentially, Sidorkin wants to replace the primary enforcer of the totalizing non-negotiable imposition in education from punishments causing educational violence to rewards of incentives, exchange of favors, or monetary compensations desired by the students. This would make education based on the totalizing non-negotiable impositions less violent, more livable, and more effective. Although Sidorkin insists on totalizing non-negotiable impositions on curriculum and instruction, his call for attention to the students' extracurricular desires or monetary compensations introduces a back channel for educational negotiation softening some of the negative consequences of non-negotiable imposition in education.

However, since Sidorkin seems to accept, if not strengthen, all justifications for the legitimacy of the totalizing non-negotiable curricular imposition (but not instructional or organizational!), my list above of challenges to this legitimacy remains applicable to his capitalist approach.

\section{Progressive approach of the Progressive School Movement}

Similar to Sidorkin's Capitalist approach, the Progressive approach also accepts the totalizing legitimacy of the society's right to define academic curriculum for the students. As one of the most influential proponents of the Progressive movement John Dewey wrote in his famous essay The Child and the Curriculum, "We get the case of the child vs. the curriculum; of the individual nature vs. social culture" (Dewey, 1956, p. 5). According to Dewey heavily influenced by Hegel, the curriculum is firmly and mainly defined by the society. He went to great lengths to explain the differences between students' experiences and societal curriculum. In short, the societal curriculum involves reified, decontextualized, and universalized societal experience and reflection. Dewey gave an example of a geographical map as such a societal academic curriculum, "The map orders individual experiences, connecting them with one another irrespective of the local and temporal circumstances and accidents of their original discovery" ( $p$. 20). Dewey saw the goal of genuine academic school learning as subjectivizing, psychologizing, and personalizing the curriculum (unilaterally defined by the society without the student's input), "Hence the need of reinstating into experience the subject matter of the studies, or branches of learning. It must be restored to the experience from which it has been abstracted. It needs to be psychologized; turned over, translated into the immediate and individual experiencing within which it has its origin and significance" (Dewey, 1956, p. 22). This process of personalization must start with the student's own pre-existing experiences and interests and expands into the curriculum predefined by the society, "If the subjectmatter of the lessons be such as to have an appropriate place within the expanding consciousness of the child [i.e., so-called "developmentally appropriate curriculum" - EM], if it grows out of his own past doings, thinkings, and sufferings, and grows into application in further achievements and receptivities, then no device or trick of method has to be resorted to in order to enlist 'interest.' The psychologized is of interest that is, it is placed in the whole of conscious life so that it shares the worth of that life" (Dewey, 1956, p. 27). 


\section{Legitimacy of non-negotiable imposition in diverse approaches to education}

Eugene Matusov

Dewey criticized both conventional schools and some innovative educators for two opposite pitfalls, "'Guidance and control' are the catchwords of one school; 'freedom and initiative' of the other" ( $p$. $10)$. In his view, conventional schools neglect personalization of the societal curriculum, while some innovative educators neglect the societal curriculum, unilaterally defined by the society (probably, through the state). Dewey also criticized the content of the academic curriculum selected by conventional schools but like conventional schools, although probably using a different reason, he accepted the legitimacy of the society to unilaterally define the curriculum and, thus, to impose the curriculum on the students. Thus, conventional schools make academic learning boring and alienated for the students, while narrowly childcentered innovative education makes learning shallow for the students,

\footnotetext{
There are those who see no alternative between forcing the child from without, or leaving him entirely alone. Seeing no alternative, some choose one mode, some another. Both fall into the same fundamental error. Both fail to see that development is a definite process, having its own law which can be fulfilled only when adequate and normal conditions are provided. Really to interpret the child's present crude impulses in counting, measuring, and arranging things in rhythmic series involves mathematical scholarship a knowledge of the mathematical formulae and relations which have, in the history of the race, grown out of just such crude beginnings. To see the whole history of development which intervenes between these two terms is simply to see what step the child needs to take just here and now; to what use he needs to put his blind impulse in order that it may get clarity and gain force (Dewey, 1956, p. 17).
}

In the Progressive approach, instruction should be negotiated with the student - the student's past and present experiences and interests, - while the curriculum is apparently and non-negotiably imposed on the essentially deficient and ignorant students. The totalizing non-negotiable imposition of the academic curriculum on the students, - i.e., what the students MUST study, - is fraught with the teacher's pedagogical violence and the student's resistance. Dewey seemed to sense this possibility and objection in his essay and rushed to a counter-argument by claiming that negotiable instruction can always negate these negative possibilities of the non-negotiable totalizing imposition of curriculum. Of course, if this negotiable instruction is done in the right way, "Guidance is not external imposition. It is freeing the lifeprocess for its own most adequate fulfillment" (Dewey, 1956, p. 17). Progressive educators are firmly convinced that for any good curriculum unilaterally defined by the society and for any particular student in any particular time, there is ALWAYS a sensitive negotiable guidance that makes the societal curriculum accepted, if not desirable, by the student, "...any subject could be taught to any child at any age in some form that was honest” (Bruner, 1986, p. 129). Well, some Progressive educators, probably including Dewey, may not go so far to claim about "at any age" because these educators would argue that for a particular (psychological rather than chronological) age, certain non-negotiable societal curriculum can be "developmentally appropriate" while others cannot.

Sidorkin $(2002,2009)$ criticizes Progressive educators for being romantic, unrealistic, and dead wrong in this belief about the unlimited power of instructional negotiation being able to make all societal "developmentally appropriate" curriculum non-negotiably imposed on the students, also acceptable and desirable by the students. He claims that from the fact that it can occur with some students at some time does not mean that it can be done all the time with all the students with any imposed curricula. The negotiable instruction has its limits. Paradoxically, the forerunner of the Progressive education, French writer Jean-Jacques Rousseau, rather cynically placed manipulation in the place of negotiable instruction to ensure that the societal curriculum non-negotiably imposed on the students is acceptable and desired by them, 


\begin{abstract}
Take the opposite course with your pupil [in child-centered, proto-Progressive, education that Rousseau advocated in contrast to a conventional authoritarian teacher-centered education - EM]; let him always think he is master while you are really master. There is no subjection so completed as that which preserves the forms of freedom; it is thus that the will [of the child] itself is taken captive [by the teacher's hidden manipulation]. Is not this poor child, without knowledge, strength, or wisdom, entirely at your mercy? Are you not master of his whole environment so far as it affects him? Cannot you make of him what you please? His work and play, his pleasure and pain, are they not, unknown to him, under your control? No doubt he ought only to do what he wants, but he ought to want to do nothing but what you want him to do. He should never take a step you have not foreseen, nor utter a word you could not foretell (Rousseau, 1979, p. 120, italics is mine).
\end{abstract}

Like Dewey, Rousseau wanted to save the child from his/her capricious, arbitrary, ignorant, and wild freedom by non-negotiable imposition of the societal curriculum that will eventually give the child power to master his or her physical and social environment. Romantic Dewey believed, as many Progressive educators still do, that instructional negotiable, developmentally appropriate, instruction can make any societal curriculum imposed on the students acceptable and desirable for the students, "A broad vein of romanticism runs through this form of progressivism, which saw learning as a natural process that would occur best if artificial mechanisms like schools and curricula would just get out of the way of children's natural urge to learn" (Labaree, 2010, p. 92). Meanwhile, a somewhat cynical Realist Rousseau called for use of skillful manipulation of the student's consciousness by the teacher to achieve the same goal.

Using Foucault's analysis of power, Fendler (1998) criticizes Progressive educators for their pedagogical desire to discipline their students into "the educated subject" - making the students desire to learn what their teacher and the society desire for them to learn. Similarly, Dan Greenberg, a founder of the Sudbury Valley School, representing the Democratic School Movement that I am going to discuss in the next section, eloquently and critically points out the crucial difference between the Progressive education and the Democratic School Movement by saying that the Progressive education wants to make students like what they are supposed to do and learn in school, while in the Democratic School Movement, students do and learn what they like (Greenberg, 1991, p. 101).

Despite the strong desire by Progressive educators to eliminate teachers' pedagogical violence and students' resistance to non-negotiable imposition of the societal "developmentally appropriate" curriculum through negotiable instruction, "double psychologizing," or (if not and!) skillful manipulation of the students' consciousness, the very desire of a Progressive teacher and the effectiveness and legitimacy of the means seem to be questionable.

Another problem with the Progressive approach is its insistence on the separation of the societal curriculum from the student's (or any human) desire. Situated cognition scholars show that universal and decontextualized knowledge, tools, and skills existing "irrespective of the local and temporal circumstances and accidents of their" usage, human desire, social relations and values are empty abstractions (Lave, 1988, 1992). Reification of human experiences and reflections remains participatory, contextualized, situated, authorial, and value-driven. Progressive educators seem to recognize the need for student's desires in learning the societal curriculum, as they criticized desireless, alienated learning in conventional schools, but they are apparently afraid that the students' desires may take over academic learning process, leading away from the well-thought preset societal curriculum. To address the latter concern, Progressive educators try to exploit students' existing desires for "psychologizing" the preset societal curriculum (e.g., "the Big Ideas"), unilaterally defined and non-negotiably imposed on the students, 


\title{
Legitimacy of non-negotiable imposition in diverse approaches to education
}

Eugene Matusov

\begin{abstract}
When the subject-matter has been psychologized, that is, viewed as an out growth of present tendencies and activities, it is easy to locate in the present some obstacle, intellectual, practical, or ethical, which can be handled more adequately if the truth in question be mastered. This need supplies motive for the learning. An end which is the child's own carries him on to possess the means of its accomplishment. But when material is directly supplied in the form of a lesson to be learned as a lesson, the connecting links of need and aim are conspicuous for their absence! What we mean by the mechanical and dead in instruction is a result of this lack of motivation. The organic and vital mean interaction - they mean play of mental demand and material supply (Dewey, 1956, pp. 25-26).
\end{abstract}

Participation and socialization in reified ready-made culture requires more than just "psychologizing" but also its active negotiation, redefining, transcendence, and even rejection of the existing ready-made culture and, thus, the students' rejection of any preset societal curriculum.

\section{Libertarian approach of the Democratic School Movement}

Although it can be probably contested, I think that the Democratic School Movement (DSM) ${ }^{12}$ started with the Summerhill School, now located in Great Britain (Neill, 1960). The core principle of the DSM is to avoid any imposition on students' desire to study or not to study,

Freedom is indivisible. It means you can never influence choice the children make. It is all or nothing. If trust in child is not absolute, the principle of Summerhill, the principle of freedom choice will lose its value (Kleindienst, 1998).

In a famous example, one of Summerhill students, named Freer, chose not to go to a single class because he was not interested in academics; rather he was interested in pottery, carpentry, and other hands-on manual activities. As a result, Freer left the school scarcely knowing how to read or write. In a later videotaped interview, the Summerhill alumnus, as an adult, he admitted that at some point of his life that required mastery of reading and writing from him, he had been angry with the school, Neill, and his father for allowing him to remain mainly illiterate but afterwards he changed his mind. He learned how to read and write rather quickly in his adult life and exactly when he needed it. All in all, he praised Summerhill for promoting his own agency and not forcing him to learn something that he did not wish to be learning at that moment. Being confident in his own agency as a free learner and trusting in his own judgment and feelings, Freer became a successful active adult having a degree in economics and he credited Summerhill for that ${ }^{13}$ (Kleindienst, 1998).

Education, especially its curriculum - what students study, - has to be a free choice of the student without any pressure from the parents, teachers and society. Curricular imposition, even if negotiable but still initiated by an adult, is usually an anathema in a DSM school, and seen as preventing students from owning their own lives. Even an attempt by a DSM student newcomer to sign him or herself in voluntarily formed classes is often viewed by the DSM school staff with suspicion of hidden pressure from parents or of the student's internalized imposition from the previous school experiences. Often the DSM school staff try to dissuade the DSM novice students from any premature and untested commitment to their academic education. Only after a newcomer has experienced the freedom of making his or her

\footnotetext{
${ }^{12}$ However, I should caution a reader against overgeneralizations. I know some DSM schools that I would not call as driven by a Libertarian approach described here. I think DSM like any organic movement involves probably a family of diverse approaches http://en.wikipedia.org/wiki/Democratic education.

${ }^{13}$ Although in the interview (https://www.youtube.com/watch?v=058xTHGYzIY), he admitted that he would not let his own children have the same schooling experience leaving the school without learning reading and writing. Unfortunately, Freer did not elaborate in the video on reasons for his claim somewhat contradicting this current praise of Summerhill and its positive influence on his life.
} 
own choices for some time, can his or her choice to engage in academic studies be trusted by the DSM staff as being truly the student's own.

However, a close look at the DSM and its organization suggests that DSM students are still subjects of impositions both negotiable and non-negotiable in diverse areas of their lives at a DSM school. These impositions are apparently viewed as legitimate by the founders of the DSM schools. First of all, DSM students are subjects of legitimate and mostly negotiable impositions coming from their peers. DSM students are openly exposed and often invited to academic and non-academic activities initiated by their peers. In classical descriptions of Summerhill School, these peer negotiable impositions remain unregulated by the school. However, in some other DSM schools in the US like the Sudbury Valley (SVS) and The Circle Schools (TCS) some of their activities may involve impositions by school staff and other students are regulated by "corporation charters" granted by the school government through negotiation with the involved students (Greenberg, 1992b; Rietmulder, 2009).

\begin{abstract}
Corporations (at TCS but not necessarily elsewhere) are chartered (and limited) to regulate certain equipment, space, or activities, but nobody is required to engage. Impositions are not curricular (i.e., learn it because we think it's good for you) but practical. It IS true that one must do what the corporations impose if you want to participate in whatever they regulate... I don't see how any corporation 'impositions' could be in the same category with curricular coercion. Here are some examples of corporation rules: 'The Science Corporation requires that you wear goggles when you mix chemicals', 'The Art Corporation requires that you wash your brushes after painting with them' (Rietmulder, personal communication, November 2012).
\end{abstract}

At the DSM schools, there are often attempts to prevent non-negotiable peer impositions in a form of peer pressure or peer violence through the school collective and democratic governance and judicial procedures, which bring us to the second form of a mixture of negotiable and non-negotiable legitimate imposition at the DSM.

The DSM schools are governed by participatory democracies involving all students even very young ones, although these participatory democracies have different forms. In a British version of DSM (Summerhill), this democracy is ontological, experiential, based on discussion of immediately experienced problems in the community and addressing them through immediate democratic decision making during the General Assembly. Meanwhile in an US version, it is mostly codified, procedural, and bureaucratized. In Summerhill School, the communal decisions are often not codified and more fluent, giving an opportunity for the Summerhill students to be governed by decisions the students made by themselves in the eventfulness of the moment. Thus, in Summerhill, there have been cycles of students abandoning all existing rules and starting all over again, moving from the turbulence of chaos to eventually alienated rules, as a new generation of students joins the school. The new generation "forgets" the experiential (i.e., ontological) reasons for the old rules and the old rules begin to be felt as alienated and oppressive. These cycles often occur to the acute annoyance of the old-time Summerhill staff of the school creating a sense of déjà vu as the headache that returns (Neill, 1960). That is why I call this participatory democracy of Summerhill experiential or ontological democracy. In contrast, in the US DSM, democratic decisions are codified, bureaucratized, and rather seamlessly passed to further generations without being renegotiated on a big scale. Often US DSM students live under a regime of the rules created in the past by the students who are already remote school alumni. The reasons and practical wisdom of these rules is often lost for some rules ${ }^{14}$, which nevertheless remain on the book (there are literally hundreds of rules on the school book). The legitimacy of these rules seems to remain in the fact that the rules can be amended, modified, or removed by the school community.

\footnotetext{
${ }^{14}$ When I visited US DSM schools, I often asked students about reasons for the rules on their books and they could not explain or even guess about the reasons.
}

Dialogic Pedagogy: An International Online Journal | http://dpj.pitt.edu DOI: 10.5195/dpj.2015.110 | Vol. 3 (2015) 


\section{Legitimacy of non-negotiable imposition in diverse approaches to education}

Eugene Matusov

In the UK Summerhill School, experiential democracy, social problem solving is organized through communal experiential (ontological), if not therapeutic, justice, in which community members (i.e., the students and school staff) decide what is just or unjust in every particular contested case brought by particular community members to the school's General Assembly. For example, when some teen female students complained about stolen makeup kits, the Summerhill General Assembly decided to select a committee to search all private drawers. However, after experiencing this decision many female members of the school including the female school staff and the girls who brought the case objected to the decision, argued against it and finally managed to persuade the community to change their mind about the searches violating privacy of the community members (Allen, Getzels, \& Getzels, 1992).

In contrast, US DSM - mostly modeled after the Sudbury Valley School- codified, procedural democracy focuses on the Rule of Law, in which a student is punished or restricted by the school only in a case of infractions of the democratically established school rules, when a pre-existing rule is broken as established by a special "judicial committee" (TCS) presenting by the students and the staff. There are formal procedures of interrogating accusers, accused, and witnesses to establish what exactly happened, what exact rule might be broken, whether it is broken, and if so, what punishment if any has to be applied to the breaker of the rule. As I observed this process at The Circle School in the US, I was astonished at how little focus was developed there around the issues of justice, sympathy, meaning, and the consequences of the events for the participants and the community at large. It felt very procedural and formalistic to me. The school staff consider these emotional, relational, ethic, moral, and meaning-making issues as to be private and interpersonal and thus inappropriate for the public governmental duty and potentially impositional and oppressive for the students. Only after reading libertarian philosopher Hayek, I became more understanding and appreciating of their argument for procedural democracy focusing on developing boundaries and conditions for individuals' activism without interference in it.

\footnotetext{
The distinction we have drawn before between the creation of a permanent framework of laws within which the productive activity is guided by individual decisions and the direction of economic activity by a central authority is thus really a particular case of the more general distinction between the Rule of Law and arbitrary government. Under the first the government confines itself to fixing rules determining the conditions under which the available resources may be used, leaving to the individuals the decision for what ends they are to be used. Under the second the government directs the use of the means of production to particular ends. The first type of rules can be made in advance, in the shape of formal rules which do not aim at the wants and needs of particular people. They are intended to be merely instrumental in the pursuit of people's various individual ends. And they are, or ought to be, intended for such long periods that it is impossible to know whether they will assist particular people more than others. They could almost be described as a kind of instrument of production, helping people to predict the behavior of those with whom they must collaborate, rather than as efforts toward the satisfaction of particular needs (Hayek, 1994, p. 113, italics is original).
}

It seems that many US DSM schools do not want to interfere in activity decision making, educational choices, and interpersonal relations among the students (and the students and the school staff) but rather to set limits and boundaries for the students' actions. I have to conclude that the imposition in the US DSM procedural democracy is much less negotiable than in the UK DSM ontological democracy.

Paradoxically, some DSM schools, ${ }^{15}$ both in the UK and US, almost brag about how conventional their academic instruction is,

\footnotetext{
${ }^{15}$ I am thankful to Jim Rietmulder, a founder of TCS, cautioning me of overgeneralization of this phenomenon to all DSM schools. More research of this phenomenon is needed.
} 


\title{
Legitimacy of non-negotiable imposition in diverse approaches to education
}

Eugene Matusov

\begin{abstract}
We have no new methods of teaching, because we do not consider that teaching in itself matters very much. Whether a school has or has not a special method for teaching long division is of no significance, for long division is of no importance except to those who want to learn it. And the child who wants to learn long division will learn it no matter how it is taught (Neill, 1960, pp. 4-5, emphasis is mine).

I learned Latin as a boy-rather I was given Latin books to learn from. As a boy, I could never learn the stuff because my interests were elsewhere. At the age of twenty-one, I found that I could not enter the university without Latin. In less than a year, I learned enough Latin to pass the entrance exam. Self-interest made me learn Latin (Neill, 1960, p. 81).
\end{abstract}

It seems to me that DSM is similar to Sidorkin in arguing that teaching and curriculum are not important for the students' education. What seems important is the fact that students can voluntary and freely choose to study. My colleagues and I explained this interesting pedagogical idea in the following matter in our paper,

\begin{abstract}
When the Summerhill students become active learners, they use the teacher's instruction as a resource for their self-initiated learning. This can be similar to a scholar's attendance at a monotonous presentation on a topic of the scholar's interest at a professional conference. It does not matter how insensitive the presentation to the audience is - as soon as the attending scholar finds the presentation relevant, the scholar puts in his or her own efforts to engage him/herself in the monotonous presentation in order to learn (Matusov, von Duyke, \& Han, 2012, p. 46).
\end{abstract}

I think that Dan Greenberg, a founder of the Sudbury Valley School (SVS), pushes this idea a bit farther. In his version of voluntary education, as soon as students want to study something they must voluntarily submit themselves and freely commit themselves to whatever pedagogical regime is designed by their teacher. Of course, students may reject this instruction and the whole class offered by an adult and this rejection will be legitimate in a DSM school - but, at least from Greenberg's description, it sounds like a teacher instruction is non-negotiable, "Either my way or highway." Greenberg even brags that he uses a very old and very traditional arithmetic textbook for his Sudbury Valley School young students and imposes the most conventional pedagogical regime with rigid timetable on them while the students enthusiastically accept it,

Sitting before me were a dozen boys and girls, aged nine to twelve. A week earlier, they had asked me to teach them arithmetic. They wanted to learn to add, subtract, multiply, divide, and all the rest. ...

My biggest problem was a textbook to use as a guide. ...

I found a book in our library, perfectly suited to the job at hand. It was a math primer written in 1898. Small and thick, it was brimming with thousands of exercises, meant to train young minds to perform the basic tasks accurately and swiftly.

Class began - on time. That was part of the deal. "You say you are serious?" I had asked, challenging them; "then I expect to see you in the room on time - 11:00AM sharp, every Tuesday and Thursday. If you are five minutes late, no class. If you blow two classes - no more teaching." "It's a deal," they had said, with a glint of pleasure in their eyes.

Basic addition took two classes. They learned to add everything - long thin columns, short fat columns, long fat columns. They did dozens of exercises. Subtraction took another two classes. It might have taken one, but "borrowing" needed some extra explanation.

On to multiplication, and the tables. Everyone had to memorize the tables. Each person was quizzed again and again in class. Then the rules. Then the practice.

Dialogic Pedagogy: An International Online Journal | http://dpj.pitt.edu DOI: $10.5195 /$ dpj.2015.110 | Vol. 3 (2015) 


\section{Legitimacy of non-negotiable imposition in diverse approaches to education}

Eugene Matusov

They were high, all of them. Sailing along, mastering all the techniques and algorithms, they could feel the material entering their bones. Hundreds and hundreds of exercises, class quizzes, oral tests, pounded the material into their heads.

Still they continued to come, all of them. They helped each other when they had to, to keep the class moving. The twelve year olds and the nine year olds, the lions and the lambs, sat peacefully together in harmonious cooperation - no teasing, no shame. Division - long division. Fractions. Decimals. Percentages. Square roots.

They came at 11:00 sharp, stayed half an hour, and left with homework. They came back next time with all the homework done. All of them. In twenty weeks, after twenty contact hours, they had covered it all. Six years' worth. Everyone of them knew the material cold (Greenberg, 1991, pp. 15-17).

Greenberg's description of his SVS math instruction is uneventful. It is purely technological. There is no description of any depth of understanding or students' exciting inquires and discoveries but rather rote memorization, rules, algorithms, drills, textbook exercises, quizzes, tests, and exams - the recognizable pedagogical attributes and means of the conventional education based on totalizing nonnegotiable impositions. I have abstracted three related benefits of the SVS math instruction from Greenberg's description and discussion of his SVS math instruction that Greenberg values:

1) a higher speed of the SVS students' learning the preset curricular standards in comparison with similar math instruction in conventional schools,

2) the SVS students' high-level unconditional cooperation with the teacher's demands once the class is freely chosen, and

3) the SVS students' own intense study efforts, high engagement, and enthusiasm to study.

The students' own purposes for these academic studies are not important: they may decide to study because of their genuine interest in subject, because of their friends go there, because they want to attend a college and do well on tests, because they want to get credentials and so on - it does not matter for Greenberg. But, as soon as they make their decision, they must submit themselves to the teacher's totalizing non-negotiable impositions. Greenberg mentions some SVS students who eventually became professional mathematicians but from his descriptions it looks like they studied mostly by themselves. The nature of their studies - how close in their self-studies these students followed Greenberg's math instruction, based on the totalizing non-negotiable impositions, - was not clear for me, as a reader of his texts. Of course, other SVS teachers may teach math or other subject differently, but that is true even in conventional schools. The issue is what is ideologically legitimate and defendable. It is not my goal here to explore the complexity of the actual practice at SVS or elsewhere but rather to focus on issues of legitimacy of non-negotiable impositions and their justifications by the educators. In general, the Libertarian approach to non-negotiable imposition in education is not very much interested in instruction or promoting critical investigation of ideas among the students. This is not apparently where the Libertarian Approach sees its pedagogical excitement and creative investment. As one of the TCS staff member told my colleague studying the school, "The focus of your analysis is learning, something important to educators, but we don't share your concern' (Alan, [TCS] staff, July 2012)" (von Duyke, 2013, p. 499). The Libertarian educators seem to be more interested in schooling experimentation focusing on children's self-initiated leisurely activities, "scaled down society," democratic governance, and/or communal problem solving rather than in experimentation with instruction or curriculum. The role of the adults (often referred as "staff" and not as "educators") is to guard and maintain this leisurely environment, while staying away from children's activities and autodidact unless being asked to help ${ }^{16}$.

\footnotetext{
${ }^{16} \mathrm{Jim}$ Rietmulder, a founder of TCS, has criticized my paper for overgeneralization and distortion of DSM in general and his school in specific. He wrote, "I think you approach an important truth when you talk about a difference in "pedagogical excitement and creative investment'. It seems fair to say that The Circle School's 'pedagogical excitement and creative investment' have more to do
} 


\section{Legitimacy of non-negotiable imposition in diverse approaches to education}

Eugene Matusov

In sum, in my observation, the Libertarian approach of the DSM has three areas for what they accept as legitimate non-negotiable impositions on its students:

1) Submission to democratically elected school rules, even though these rules might be voted in by previous generations of the students and/or a student might not fully or at all understand the rationale for this rule. The legitimacy of this non-negotiable imposition is justified by democratic collective decision making, by a possibility for each student to initiate changing or repealing any existing school rule, by preventing (adult, peer, or collective) unilateralism and arbitrarism, and by the rules being constrains as well as spaces for students' creativity and activism - i.e., anything that is not explicitly forbidden by the democratically accepted school rule is permitted.

2) Acceptance of the punishment as a result of a participant's transgression of the school rules passed by the school's General Assembly (Summerhill) or by Judicial Committee consisting of peers and teachers (SVS and TCS) even though the student might not understand the broken rule or feel that the punishment is fair or unjust. The justification of the legitimacy seems the same as in above in point 1.

3) Voluntary submission to the teacher's epistemological and pedagogical authority - almost like, "If you come to me to learn, do it my way or else find another teacher or another way to study." If a student wants to study something and asks the teacher for help, the teacher can legitimately impose non-negotiable ways of study - a detailed curriculum, and instruction, as Neill and Greenberg argue.

The Libertarian approach to non-negotiable imposition in education focuses on promoting the individual agency of a student by promoting the students' self-generated activism constrained by communal non-negotiable impositions. Also, it apparently rejects the notion of the sociocultural origin of human agency (Dewey, 1956; Suissa, 2010). The Libertarian approach emphasizes their belief in:

1) the natural individual growth of students (and people in general),

2) individual autonomy, and

3) the priority of non-educational goals like psychotherapy (Summerhill), socialization in a scaled-down democratic society, "owning one's own life", and "practicing life" (Sudbury Valley School and The Circle School) over education per se (as dealing primarily with learning, as critical examination of the life, self, and the world, and secondary with guidance).

Adult-initiated guidance on academic matters, outside of social and communal conflicts and governance, is often viewed as exclusively driven by non-negotiable imposition that can be legitimate only when the demand for such unilateral guidance is genuinely requested by the students themselves. At times some DSM famous educators seem to equate academic education with transmission of knowledge of the Totalizing approach and/or socialization in the preexisting practices (the charge brought by Dewey, 1956) and/or constructivist teaching associated with the Progressive approach ${ }^{17}$.

In many DSM schools, critical examination of ideas and values in what can be called "academic" areas (e.g., math, science, art, and just existing sociocultural practices) remain non-imposed. Rather they are private, accidental, responsive, and unguided by adults, at least, not purposefully, (and, even, undervalued sometimes). In DSM, critical examination of ideas can be communal, discursive, collaborative, and purposefully guided by adults but it is usually limited to solving interpersonal problems

with democratic schooling, and less to do with the particular instructional methods that are practiced within the school. On the other hand, OSE's [Open Syllabus Education, see below in the paper] "pedagogical excitement and creative investment" have more to do with the process that takes place between teachers and students within a class. TCS is more concerned with conducting a school, and OSE is more concerned with conducting a class. I think this correctly identifies a difference in focus, between TCS and OSE. But I think you may draw too much from it. The difference in 'pedagogical excitement and creative investment' does not imply 'disinterest in academic learning'" (personal communication, 2012-11-19). I welcome and highly appreciate his criticism (and patience with me as an outsider observing and questioning TCS and DSM in general). I still feel that I both capture important aspects of the Libertarian DSM approach but also need to work more on nuancing my portrayal and critique of it.

${ }_{17}$ This is not always true for all DSM and all the time. See more nuanced discussion in von Duyke research report (2013). 
in the community and/or about democratic governance. My impression of the Libertarian approach so far is that it seems to disregard and if not to actively reject collaborative guidance that is actively and purposefully initiated by adults. This also includes adult initiated critical investigation of ideas and considering alternatives in the academic sphere (but is often OK for certain social and communal problems and governance), which are considered to be illegitimate non-negotiable or even illegitimate negotiable impositions by adults, messing with the students' natural agency and its growth. Thus, in my analysis, the Libertarian approach provides freedom, but not necessary resources and sufficient support for developing students' agency when they are not yet at a level of self-generated authorship. Thus, von Duyke reports that some DSM students may temporarily go to conventional schools to get exposure and responsive authorship for diverse academic practices to nurture their own academic interests. After getting sufficient exposure that sparks their own self-generated authorship in these practices they may return back to a DSM school (von Duyke, 2013). Responsive and critical authorships beyond communal life (Summerhill) seem to be neglected and depreciated in certain Libertarian DSM schools.

Finally, I wonder if the success of DSM schools, evident in critical thinking of many DSM students and alumni, may in part be based on utilization and complementation of the middle class parenting famously studied by Lareau. Lareau found that while working class parents view their goal in supporting their children's "natural growth", middle class parents define their parenting goals as "concerted cultivation" through organizing special extracurricular activities for their children (Lareau, 2003). It seems that DSM schools promote the natural growth in a rich learning environment at their schools, while the middle class parents of their students provide the concerted cultivation at home. Although the Libertarian approach subordinates education to the natural growth of agency and socialization into a democratic society $^{18}$, it is still amazing that almost all of its students eventually and voluntarily choose some form of engagement in academic learning. This sharply contrasts with the working class cultural upbringing described by Lareau who characterizes it as "accomplishment of natural growth" (Lareau, 2003), which is somewhat similar to the Libertarian approach focusing on promotion of natural agency through autonomy. However, the working class cultural upbringing does not lead to children's voluntary engagement in academic studies on any systematic basis, while the students' voluntary engagement in academic studies has been demonstrated by the Libertarian approach. The biggest difference between them is that the Libertarian approach promotes students' democratic self-governance heavily shaped by the adults while a working class cultural upbringing does not. However, it is unclear whether and if so how this difference may contribute to the difference in children's self-engagement and self-commitment to academic learning. I wonder if the Libertarian approach and/or middle-class cultural upbringing of most of its students, which is focused on "concerted cultivation" (Lareau, 2003), have hidden non-negotiable impositions exploited by the DSM schools. It can be possible (and verified by at least one TCS high school student) that peers, college expectations (and anxieties), and the fact that the place is called "school" creates hidden nonnegotiable impositions about academic learning and even academic curricula in the DSM for mostly middle-class students who may set the communal culture of the place. More research is needed to address this interesting phenomenon.

Anarchist approach of the Open Syllabus Education I

The concept of the Open Syllabus Education (OSE) is relatively simple. Instead of having all educational decisions being made by the teacher, school, and state as it is normally done in the Close Syllabus Education (CSE), in OSE all educational decisions - what to study, when, how, why, how to

\footnotetext{
${ }^{18}$ Cf. Greenberg, "In effect, we have designed our ideal Information Age school - the Sudbury Model school. It's a place where, in order to provide an environment where children can grow to be effective adults, we allow Nature to take its course. We allow kids to grow up freely, and do everything we can to get out of the way, giving support only when they ask for it. It's a place where children are allowed to do whatever they want, because we know that they're trying with all their might to become independent adults." http://www.sudval.com/essays/092011.shtml
} 
assess it if at all, and how to organize it (including the decision of whether or not to use OSE) - are made by the students themselves, "a good school is the freedom to establish its own direction" (Farber, 1970, p. 39). The OSE approach is not new and apparently runs rather long in history and in diverse places and settings from Socratic dialogues, especially in Meno, (Plato \& Bluck, 1961), to modern "Socrates café" (Phillips, 2002), "learning circles" organized by prisoners of the South African apartheid (Mandela, 1995), calls for "deschooling society" and "educational networks" (Illich, 1983), calls for learning from and with students (Rancière, 1991), homeschooling (Llewellyn, 1998), "empowerment of students" (Farber, 1970; Shor, 1996), and so on. Recently my colleagues Ana Marjanovic-Shane, Mark Smith, and I have joined similar efforts by Scott Richardson, who started his OSE pedagogical experimentation before us (Marjanovic-Shane \& Matusov, 2012, October; Matusov \& Marjanovic-Shane, 2012, March; Smith \& Correa, 2012, February). So far, in our own OSE practice in higher education, my colleagues and I have distinguished two forms of OSE: Anarchist and Communitarian.

In contrast to the Libertarian approach of the Democratic School Movement, in the Anarchist approach, the role of the teacher is viewed as more active, more collaborative, more dialogic, more critical, and more educational. The OSE teacher is seen as a tour guide to a foreign country on an invited journey with the students. The OSE teacher feels responsible for providing an initial curricular map of what is possible to study, supporting the students' inquiries and choices, bringing alternative ideas and their sources, engaging the students in testing their own and other people's ideas, evaluating their own values, validating their contributions, offering his or her suggestions, and so on. In other words, the OSE teacher is not afraid to impose his or her guidance; however, this imposition is mostly negotiable and suggestive. The final word always remains with the students, seeing the students as the ultimate and "final authority for their own learning" (Klag, 1994). In the Libertarian approach, educational suggestions initiated by the teacher often seen as inappropriate curricular impositions or calling for "entertainment" of the students (von Duyke, 2013).

Also, in contrast to the Libertarian approach, in the Anarchist approach, OSE students may opt out from the OSE and demand a Closed Curriculum unilaterally designed by the teacher, which will be still OK in the Anarchist OSE. Although Libertarian educators may support non-Libertarian educational institutions as legitimate educational alternatives to their own schools for those students (and parents) who have chosen them, it is doubtful that Libertarian educators of DSM would allow their students to impose non-Libertarian practices in their school such as grades, mandatory attendance of classes not freely chosen by the students, no democratic government, and so on (at least, these Libertarian educators would probably move away). As an Anarchist educationalist, Farber points out, "If schools are free, some of them may choose to renounce a part of their freedom. There may be students who prefer to be dictated to. For all I know there may always be students who want to be graded daily and threatened with probation, dismissal and so on, just as there may always be persons who want to be flogged and will no doubt always find other persons willing to do it. It is certainly not my wish to prevent them" (Farber, 1970 , p. 42). Students who choose to opt out from OSE by demanding a conventional education (or some other) are still viewed as being a part of (Anarchist) OSE as they design their education in that way.

I call this approach "anarchist" because of its belief against any non-negotiable impositions, in self-organization, in the students as being the ultimate and final authority of their own learning, in dialogic and critical testing ideas, including values of the students' own education, in its respect for the students' non-cooperation and non-participation, and, finally, in its high value of guiding negotiable impositionssuggestions provided by OSE teachers to their students.

In contrast to the Educational Libertarian approach that sees student agency as mostly individual and natural, the Educational Anarchist approach views student agency as sociocultural and socially constructed, rooted in critical dialogue. I see an important difference between Educational Anarchist and Educational Libertarian positions: the Educational Libertarian position is much more insisting on students' epistemological autonomy, while Educational Anarchism is not, focusing on critical dialogue. This 
Anarchist approach of the OSE tries to avoid or minimize any non-negotiable impositions in education coming from the society, institution, economy, teacher, and peers as much as possible ${ }^{19}$ while promoting negotiable educational impositions in a form of suggestive initiatives brought by the OSE teacher for the students' own considerations. Of course, the students are free to add their own suggestions - negotiable impositions. Thus, at the end of each class meeting, OSE students decide what topic they want to discuss next time: to stay longer on the same topic, to select a new topic on the curriculum map list, or propose a new topic that is not on the list. The collective decision-making, in itself, is a result of collective negotiation - it can be done by voting or by consensus or by dissenting individual students pursuing their own topics, which is another decision that has to be made by the OSE students. The student attendance, grades, preparation, homework are all ultimate decisions by the OSE students within the institutional constrains that the OSE teachers and students find themselves.

Like Shor (1996) and Ferber (1970), our OSE pedagogical experimentation has occurred in the context of conventional institution ${ }^{20}$ of higher education mostly at the undergraduate level with a high degree and long history of non-negotiable impositions on the students (and the teachers) (Avila, et al., 2001). We have "lessons" (i.e., clock-based time), "classrooms" (i.e., sterile physical environment), "grades" (i.e., summative assessment), forced enrollments (i.e., forcing the students to take our classes), and students' engagement in other, non-OSE, classes in parallel to our OSE classes. This is very different from the Libertarian DSM many of which are private schools with much more leeway (i.e., "freerange" or "bigger cage" OSE). However, surprisingly our institutions provide substantial leeway for how most oppressive educational practices can be organized. For example, these institutions may require final grades but often do not specify how these grades must be organized leaving this decision entirely to the instructors, which the OSE teachers can pass to their own students who may decide to pre-emptively assign unconditional As to themselves and, thus, essentially annihilate the conventional educational practice of summative assessment.

Currently, after about four years of experimenting with the $\mathrm{OSE}^{21}$, I have experienced several concerns with this Anarchist approach. In my not very long pedagogical experience and observations, the OSE generates diverse forms of learning activism, initiatives, collective decision-making, critical dialogue, and self-governance in students. It also generates diverse forms of participation and non-participation. In this regard, I see several major related pedagogical concerns with OSE.

First, when all learning activities are suggested and not required by the instructor and/or by peers, some or even all students may not try new learning experiences that they might find important if they had been imposed upon to try them. As one student reflected on OSE after the class of mine in a solicited anonymous survey (June 2012), she had ambivalent feelings about OSE, "I liked the open syllabus, but I thought it took away from some of the learning opportunities. I took a class with Eugene last fall, which had more non-negotiable learning activities. I thought that the index cards, webtalk, questions, and course assignments were more useful with non-negotiable assignments, because there was more engagement with us all doing the same assignments. However, I really liked the open syllabus, because I could pick and choose which learning opportunities would benefit me for my own research interests. However, I still engaged around all the course content, because I wanted to expose myself and learn

${ }^{19}$ In general, the OSE agrees with non-negotiable impositions when the issue of the participants' survival is at stake: be it institutional, physical, emotional, relational. Of course, OSE teachers would grab a student on a street to save him or her from getting hit by a car while trying to cross a street. However, they would hesitate engaging in non-negotiable impositions around educational issues unless they put the limits to their Anarchist approach to impositions.

${ }_{20} \mathrm{Jim}$ Rietmulder, a founder of TCS, convincingly argues that this context of totalizing conventional educational institution in which OSE educators work creates unescapable conditions of OSE teachers being "benevolent dictators" who grant their students pedagogical freedoms on their own wish. These freedoms remain on the mercy of OSE teachers, complicated by OSE teachers' personalities, their good will, students' trusts in the OSE teacher's promise not to revoke their rights, and the teachers' pedagogical mistakes that may undermine this trust (personal communication, January 2013). I tend to agree with this claim.

${ }^{21}$ This pedagogical experimentation with OSE has included deviation from the Anarchist Approach at times by introducing NonNegotiable Learning Activities unilaterally designed and imposed by the OSE teachers in some of my OSE classes (but not in all of them).

Dialogic Pedagogy: An International Online Journal | http://dpj.pitt.edu DOI: 10.5195/dpj.2015.110 | Vol. 3 (2015) 


\title{
Legitimacy of non-negotiable imposition in diverse approaches to education
}

Eugene Matusov

about topics I was not familiar with." It seems that the Anarchist OSE may rob students of important and valuable learning opportunities, emerging from serendipity and the teacher's epistemological and pedagogical authority (Matusov, 2007, 2009; Morson, 2004), which they might experience in the conventional Closed Syllabus classroom or in the Opening Syllabus ${ }^{22}$ pedagogical designs, involving nonnegotiable imposition. At the same time, the students do not want to have these important learning experiences imposed on them anymore - I suggested that but they rejected my suggestion. Some may argue that this sentiment of missed learning opportunities may be an important learning experience in itself, waking up the student's learning agency.

Second, coming from conventional monologic schooling shaped by Closed Syllabus Education, many students have been tired of "performing academics" (a student's term) rather than learning for their own sake. In the Anarchist OSE environment of suggestions and learning opportunities, they may require or be tempted to take an "alienation vacation" (Matusov \& Brobst, 2013) - i.e., minimum participation in the classroom. Some educators of the free school and homeschooling movements (Greenberg, 1991, 1992b; Llewellyn, 1998; Neill, 1960) have noticed that and suggest letting students go on these alienation vacations for a while as a necessary process of school detoxification,

\begin{abstract}
When you quit school, do nothing academic for at least, at the absolute minimum, a week. If you wish, however, write stories or journal entries about your past and your future. Dream, dream, dream. If you crave TV, watch it. If you crave sleep, indulge. Allow yourself to go through withdrawal. Pass no judgments. If you want to "work" on anything, work on forgiving and forgetting. Forgive yourself for everything. Forgive your teachers for everything. Forgive your parents for everything. Forget the lies school taught-forget that learning is separate from your life, that you can't teach yourself, that you are defined by your grades, and all other such nonsense. Detoxify. Purge (Llewellyn, 1998, p. 126).
\end{abstract}

This is a difficult, if not impossible, advice to follow for a student and an instructor in the context of 15-week semester with other conventional classes demanding "academic performance" rather than selfinitiated learning, especially when it may take months and years before full school detoxification and recovery occurs for some students as Neill reported in one case (Neill, 1960, p. 2). Meanwhile, in the context of the Anarchist OSE, the need for school detoxification and alienation vacation may rob some students of important learning opportunities and I seemed to observe these cases.

Third, I wrote "I seemed to observe" my students in their alienation vacation because coming from traditional monologic teaching where all students are expected to participate in the same required learning activities at high levels of engagement, I am not sure if I may have wrong pedagogical expectations and desires about students' self-generated participation in their own learning when such opportunities are given to them. At the time of taking the class or just because of the students overall learning trajectory and interests, some students may require more peripheral participation (if at all) than other students. Life outside of formal education institutions encourages and often legitimizes learners' diverse forms and intensities of participation and non-participation in activities. As one OSE student wrote to me in an email explaining her frequent missing the class,

\footnotetext{
In short, I am having a terrible semester. I have bit off more than I can chew in having a part time job and taking 2 honors classes as well as extracurricular activities. When I miss class it is because I am either working extra hours at work or I am cramming for my next exam. I realize I have not been the ideal participant in our class but I can assure you I do really enjoy our EducXXX class and the topics we discuss. Urban education is a passion of mine and I looked forward to this class until I became so stressed this semester. It probably obvious to you,
}

\footnotetext{
${ }^{22}$ This pedagogical design involves a gradual or abrupt transition from Closed Syllabus Education to, or in direction to, Open Syllabus Education within a class term without directly starting with OSE.
} 


\section{Legitimacy of non-negotiable imposition in diverse approaches to education}

Eugene Matusov

as well as to myself, that because of our open syllabus and "no grades" policy, that I have used this class as a cushion for my heavy workload. I apologize because I know I have taken advantage of what was supposed to beneficial to my learning and our class. I don't know how to make up for the class time that I have missed except to tell you that I really have enjoyed what I have been there for and that I have tried to use webtalk to understand the days I missed. I hope you see that when I am in class I enjoy participating and have a lot to offer $^{23}$ (email, November, 2012).

On the one hand, I try to work hard on breaking the conventional Assignment-based Chronotope of education by diversifying mediums and forums of education to incorporate students with diverse educational needs and life circumstances. On the other hand, I remain torn between these possibilities legitimizing low involvement of some students and my concern that I need to improve my guidance to engage these students (and stop rationalizing my teaching failures) or that the Anarchist OSE may not work for some students with low will - but, alternatively, how can a student's will be developed if his or her opportunities for taking control of his or her learning is constantly taken away by imposed requirements?! Am I accepting and respecting students' non-participation and non-cooperation OR am I accepting my own pedagogical laziness, conservatism, and impotence? Do I have a wrong pedagogical desire of making all of my students like and highly engage in our class or am I trapped by conventional educational institutional practices and relations that I uncritically accept? Am I trapped by my Educational Anarchist ideology, dear to my ideological heart, that I am in denial of its insensitivity and ineffectiveness for some of my OSE students? Where are limitations of my responsibility for students' education when I accept that the students are the highest authority for their own learning? Should some graduate approaches like Opening Syllabus Education, where learning freedoms increase gradually through the course by promoting choices and engaging students in decision making about the organization of the class and their learning, be used for these students? Giving a lot of freedom at once to people with a long history of educational oppression by the totalizing non-negotiable impositions may be as detrimental, if not deadly, for the students' learning agency as giving unlimited food to people who experienced prolonged and intense starvation. As we do not give too much food to starving people, should initial freedom of learning be limited for students who are severely traumatized by conventional oppressive schooling? Some students may desire to be forced while disliking being forced or imposed, which can be a paradox in itself (or, alternatively, a vicious circle of distrust in and surrendering one's own agency).

Genuine education may require leisure from the students as a way of their living free from most necessities. As the student's quote above shows, when even highly willing and motivated students get freedom from imposition they may use this freedom to do things that are imposed on them by somewhere else and by somebody else rather for their own educational self-actualization that they may highly desire. The Ancient Greeks, who invented the term "school," defined it as "leisure". "School" means "leisure" in Greek (Arendt, 1958). Ancient Greek citizens were free from major necessities and labor thanks to slavery. To be a citizen of a Greek city-polis, one should not be just a free citizen (i.e. not a slave) but also be free from labor (Arendt, 1958; Gorz, 1989). In contrast, modern society and modern schools are necessity-based. We do many things in our everyday life because often it is required by circumstances of our life or by other people. Although conventional education has freed children from physical labor and chores, it invented imposed assignments that colonize a huge part of the students' lives. It may be that the Anarchist Open Syllabus is incompatible with our current society. However, there are signs that the modern economy with its increasing robotization and automation leads to diminishing need for human

\footnotetext{
${ }^{23}$ In my view, the student's experience of deprioritizing her desired learning and reflection on it, promoted and supported by the instructor, is very important for students' development of her learning agency as an active learner. The student volunteered to discuss this point in class at the end of the semester when a visitor came and asked the OSE students about their experiences with the OSE.
} 


\title{
Legitimacy of non-negotiable imposition in diverse approaches to education
}

Eugene Matusov

labor and that a leisure-based society may again emerge but this time without slavery (Ford, 2015). It may be that the Anarchist Open Syllabus is an education of the future.

Fourth, by encouraging the students' personal learning activism and meaningfulness of their learning, the Anarchist OSE pedagogical design encourages the students to initiate personal learning journey and self-assignments that may not have a collective focus for the class. As one of my former OSE students, who took two of my classes - one, first, with an Opening Syllabus Education design (EDUCXXX) and the other, second, with an Open Syllabus Education design - wrote in his/her anonymous survey after the class (2012-06),

\begin{abstract}
I believe my answer (Limited open syllabus) was the way EDUCXXX was run (if not, that what I intended my answer to be). In EDUCXXX I like that we had certain assignments "forced" on us, but the topic, scope, etc. was always at our discretion. I think "forcing" some assignments provides an opportunity for shared experiences and classroom culture. This semester seems a little disorganized in the sense that everyone was doing what was best for them (which I like), but what is best for you might not necessarily be what is best for the group. I guess I am struggling with how best to balance the individual as a member of a group?? I also like voting on the topics from a wide variety of possibilities so we could explore what interested us instead of what you thought would interest us. I wish more professors provided that opportunity (but I understand why they don't b/c it's a lot of work for you!) I missed Webtalk this semester as well, so I wish that was "forced" in some way.
\end{abstract}

Some successes of the Anarchist OSE may lead to diffusion of the collective focus of the class, which by itself can be less problematic as individual foci may be no less important - actually some of my OSE students complain of too much collective pressure in our class demanding the shared focus on a particular curricular topic that they might not be interested in or prioritized ${ }^{24}$ (for this reason I envy the Libertarian approach of DSM in which students do not seem to have this collective curricular pressure). However, as the student pointed out, some learning activities and practices may require a critical number of participants for its success (e.g., forum work, providing peer reviews and peer feedback, discussions). There seems to be a need for this student for impositions that create social possibilities for dialogue and also for freedom of content. More experimentation and investigation of OSE is needed, in my view.

Finally, the OSE students are mostly involved in intellectual Internally Persuasive Discourse about their education rather than ontological Internally Persuasive Discourse. The Anarchist approach of the OSE presents decision making processes and testing ideas mostly as intellectual choices about their own education for the students to consider before their ontological experiences, "Do you want to study this topic or that next time? Do you want to do a particular project or not? How do you want to make decisions in our class?" and so on. I call these choices "intellectual" because, although OSE students may have past experiences with some of these choices, often these are hypothetical possibilities for them to consider $^{25}$. Of course, in the Anarchist approach, the students ontologically experience the consequences of their intellectual decision making but they do not experience and compare diverse ontological possibilities. Ontological choices of comparing and testing lived experiences of diverse educational organization by the students are usually peripheral for the students. In the Anarchist approach, the OSE students are usually faced with making decisions about alternative organization of their educational experiences before their alternative experiences.

\footnotetext{
${ }^{24}$ Some of my OSE students started their own individual studies not unlike I saw in DSM. I encourage and academically support these studies with my guidance.

${ }^{25}$ Cf. Oscar Wilde's similar criticism of (Anarchist) Socialism, "The trouble with Socialism is that it takes too many evenings [for constant decision making]."
} 


\section{Communitarian approach of the OSE II}

Visiting my OSE colleague Scott Richardson's graduate seminar in early December 2012 (almost at the end of Scott's university semester) made me realize that our OSE approaches to non-negotiable imposition in education were somewhat different rather than simply being variations on more or less the same Anarchist approach. I call the approach I saw in his OSE class Communitarian. I see as the most important, but not the only, difference between the Anarchist and Communitarian OSE approaches, the fact that in the Anarchist OSE, the individual students' educational and organizational decisions are mostly not imposing on each other while in the Communitarian OSE they are.

I started suspecting the difference in our approaches when one of Scott's students shared that she found the OSE organization of the class unhelpful and ineffective for her as a learner who "needs more structure and rewards." I asked the student if she shared her concerns with the class and the instructor at some point during the semester. Based on my own (Anarchist) pedagogical experience with OSE, I expected Scott to be willing to design a more conventional educational regime for this student at her request. In the past, when I sensed similar dissatisfaction in my OSE students with the OSE pedagogical regime of our class, I privately offered to these students (and everybody else) an opportunity to change the pedagogical regime in whatever way the students felt comfortable with. I explicitly offer an option in which I (the teacher) impose assignments and grading on the students if this is what an individual student wants to return to, i.e. an option of conventional pedagogical regime. So far, none of my students chose this option because, according to them, even when they leaned toward it, they did not want to lose the obtained freedom of our class. However, I am always ready to create individualized plans $^{26}$ as a part of the Anarchist OSE that almost demands the individualization of the pedagogical regime for the needs and wants of individual students. However, to my surprise Scott's students did not find my OSE pedagogical practice as a "natural" response to this student's complaints. Rather they tried to convince the complaining student that she had learned in their OSE class much more than she might perceive at the moment. The student replied to my suggestion for a possible individualized plan negotiated with the instructor that she did not want to be an "asshole" who would hold back the entire class from being enthusiastic about the $\mathrm{OSE}^{27}$.

\footnotetext{
${ }^{26}$ Other individualized organizational variations do occur in my OSE classes.

${ }^{27}$ My colleague Jim Rietmulder, a founder of TCS, wrote while reading this passage, "This was a class of educators and educatorsto-be. I wonder if everybody's expectations would have been different if the class had been, say, molecular biology instead. I think education classes tend to operate on two levels, in a way that is not true of non-education classes. Like all classes, education classes highlight the course material, but education classes are also self-referential or at least self-conscious. In addition to highlighting course material, they are living examples of the material under study. I wonder if that's relevant." In my view, it is both relevant and not. It is relevant because the educational practice of our OSE classes is its curriculum, in contrast to a class, let's say, on molecular biology. In our OSE classes, the students' ontology (i.e., how they experience the class) matches the class epistemology (i.e., the students' intellectual focus). It is not relevant as I believe that a molecular biology class can be run as OSE on any level (i.e., grad, undergrad, high school or elementary school) because I believe any class can be involved in the practice of its study.

Somewhat similarly, my colleague Robert Hampel raised another related important concern, "You draw examples [of OSE classes] from courses where the curriculum seems much more flexible than it is (IMHO!) in the science (and a few social sciences like economics). If I want to follow my own interests in physics, could I?" (personal communication, January 2013). Interestingly, I personally experienced and learned about proto-OSE in math and physics courses in my innovative High School in the Soviet Union (famous Moscow school 91), probably because these subjects were under lesser ideological Communist control. In those course, my teachers used ontological provocations that led students to explore the math and science curriculum (see a similar innovative pedagogical practice in teaching physics, Mazur, 1997). Usually, educators are concerned about the subject systematicity versus fragmentation. I see at least two issues in this concern. One issue is about the source and the nature of the subject systematicity: imposed systematicity versus emergent systematicity. The conventional pedagogical view is that the subject systematicity is rooted in the curricular subject itself (i.e., the logic of the curricular unfolding), especially when the subject is fact-based (like sciences) and not opinion-based (like humanities and art). A dialogic pedagogy view is that any curricular subject is meaning-based and thus authorial and requires emergent student-based systematicity. Another issue is about the structure of the systematicity (i.e., curricular narrative - how the subject curriculum is unfolding in time of the study). A conventional pedagogical view on the systematicity structure as a linear progression from concrete to abstract (or vice versa), from simple to complex, from the fundamental (e.g., math axioms) to differentiated (e.g., math theorems), and so on. A dialogic pedagogy views the curricular narrative as biographical that is unfolding within personal interests, needs, and events. More research on this is needed.
} 
It turns out that in contrast to my Anarchist OSE classes where each student can legitimately make a decision only about him/herself and, thus, are viewed as individual pathfinders; in Scott's Communitarian OSE classes, the student group's decisions are binding on all students. Scott and his students call it, "being accountable to each other." Scott's students imposed on each other assignments, summative assessments (i.e., real grades), attendance requirements, retributions (e.g., a student who missed a class must bring food to a next class), and so on. In the Communitarian OSE, educational nonnegotiable impositions are horizontal coming mostly from peers rather than being vertical coming from the school institution and/or teacher as in conventional schools. The collectively organized educational student communes of the Communitarian OSE remind me of the pedagogical experiments in the Soviet Union by Anton Makarenko in the 1920-1930s (Makarenko, 1973) and by the Communard movement in the 1970-1980s (Sidorkin, 1995).

One striking difference, which I have noticed, between Scott's Communitarian OSE class and my Anarchist OSE classes (both graduate and undergraduate) is a much higher degree of students' activism, social engagement, and ownership in Scott's classes. Scott starts the class with asking his students, "What are we going to do today?" after which his students take over the discussion and investigation of the inquiries at hand while Scott provides important guiding challenges, exposures, and summaries. In contrast, in my Anarchist OSE classes, although a topic for the class is chosen by my students, they expect me to prepare a lesson for them, provoking a critical discussion and investigation of emerging inquiries with me having a firm role of the leader of the discussion. In my judgment, on average, his students, having more commitment to their own education probably through "mutual accountability," come to class much more actively prepared than my students. I sensed their attitude demanding their own education from themselves, each other, and Scott, while my OSE students' attitude is often more expecting me to provide education to them for their consumption. I envy Scott's role in his class and learning activism by his students. My Anarchist OSE classes seem to be focused on promoting more students' responsive authorship through my dialogic provocations while Scott's Communitarian classes seem to be focused on promoting more students' self-generated authorship, although both types of dialogic authorship are apparently present in both types of OSE classes (Matusov, 2011; Matusov \& Brobst, 2013). It can be that I'm doing my Anarchist OSE instruction poorly by taking over from my students and frankly talking too much in class. Alternatively (or in addition), the difference may be rooted in the approaches themselves. In the Anarchist OSE, the teacher is equal to the students in terms of his/her power only to suggest and not to impose - students cannot impose on each other in the same way as the instructor cannot impose on them. In contrast, in the Communitarian OSE approach, the teacher seems to have lesser official power than the students who can impose on each other while the teacher cannot. Also, peer impositions may throw the students more in social engagement and organizational and learning activism. Finally (another alternative), student learning activism may take more time for development in the Anarchist OSE.

However, I suspect that a Communitarian OSE teacher may have more tacit power than an Anarchist OSE teacher than it looks like by becoming a charismatic leader, as it happened with Makarenko and the Soviet Communard movement, curtailing students' independence, critical thinking, and autonomy,

Independence in thought and action is curtailed in Makarenko's conception of the collective to such an extent that creativity ultimately is denied its most fundamental outlet-art... When one of Makarenko's charges expressed a real desire to become an actor, Makarenko felt duty bound to dissuade the youth. It is likely that Makarenko distrusted those activities he could not control personally; his heavy hand is seen in many of the decisions made by the nominally autonomous Commander's Council (Caskey, 1979, p. 281).

Dialogic Pedagogy: An International Online Journal | http://dpj.pitt.edu DOI: 10.5195/dpj.2015.110 | Vol. 3 (2015) 
Having the epistemological authority of a tour guide in a foreign country (or "a bus driver," Scott's metaphor) in the context of another authority based on peer collectivity for non-negotiable impositions, a Communitarian OSE teacher can quickly jeopardize check and balance of power by tacitly controlling the class and making the students "educated subjects" (i.e., making students want what the teacher wants them to want) similar to the Progressive approach. In other words, in my view, a Communitarian OSE may not provide a check on "majority despotism," or better to say since it does not need to be based on majority, "collectivity despotism" either shaped by the OSE teacher or flying by itself coming mostly from the students as peer pressure, in which a dissenter may feel like an "asshole" and "spoilsport," holding back the community (cf. Golding, 1999; Huizinga, 2009).

The Anarchist OSE approach may also have a communitarian flavor if students choose to accept bounding democratic decision making. However, in contrast to the Communitarian OSE approach, in the Anarchist OSE approach any student can withdraw his or her consent to binding collective decision making at any time without much hassle as it happened in one of my Anarchist OSE classes. A spoilsport dissenter is welcomed and valued in the Anarchist OSE for promoting liberal democracy and critical education (Marjanovic-Shane, 2015, in preparation). This right of students for their own path finding creates its own, Educational Anarchist, collectivity based on critical dialogue of everything "becomes dialogically tested and forever testable" (Morson, 2004, p. 319), in which voting or a past rule can never replace critical persuasion. The right to be different, to be the Other, and, thus, to leave the collectivity bind of "mutual accountability" at any time for any reason, no question asked, is the inalienable right in the Anarchist OSE approach and this right is probably what defines the Educational Anarchist approach (Kukathas, 2003).

Why are my OSE classes driven by the Anarchist approach while Scott's OSE classes driven by the Communitarian approach? Is it coming from the OSE instructor or from the OSE students or from both? I can be wrong in my guess to this inquiry that requires more systematic investigation but I think it is both with more responsibility coming from the OSE instructor. Looking back, I have noticed that Scott has been using a more Communitarian philosophical discourse in justifying his OSE pedagogical approach while I have been using a more Anarchist philosophical discourse. Also, on several occasions some of my OSE students wanted to punish their classmates for a lack of their engagement in the class (e.g., many absences). However, my other OSE students and I actively, and so far successfully, resist this idea arguing that it would be the end of the OSE because "we cannot make decisions about other people without their consent."

Looking back, I have also noticed occasions when the Anarchist nature of my OSE classes was defined by my students first. In one of my graduate OSE seminars, a student refused to accept a prior collective class decision voted in by a majority and demanded a vote (with my support ${ }^{28}$ ) on making all collective decisions to be suggestive and not binding. The class voted on her proposal unanimously approving it and, thus, inaugurated the Anarchist OSE, turning away from an essentially Communitarian OSE.

Since these tensions usually occur later in the semester, when Anarchist decision making processes are firmly installed, - by seeking Quaker-like consensus with everybody having the right to

\footnotetext{
${ }^{28}$ My support was basically limited to a suggestion when the class erupted in frustration and turned to me for help, "I guess we need to make a decision on Rita's proposal." Thus, I framed it as a legitimate proposal (rather than an "illegitimate coup or rebellion" or "illegitimate insubordination" to a previously adopted collective decision). I wonder what Scott would do in a similar situation.

Scott replied, "Hmmm...not sure I understand everything...my general stance in any sort of chaos (as perceived by students) is to 1) simply narrate the tensions - tell a history of sorts as to the situation they are in (so they can simply 'see' the situation) and 2 ) then throw my hands in the air and say, 'it's your education, I think it's important for you to work out how you'll best learn...' 3) step back say very little more in class 4) individually check-in later (not to undermine the agreements made or others, but just to reassure them that this frustrating work is worthwhile and to continue to find the best ways to advocate/articulate their learning needs), 5) make 'light' of the conflict by sending an email- 'I'm so impressed with the sophistication of this issue...what you are doing is important because...' (it is my attempt to not make it 'personal' between students, but 'intellectual'). I found my role has to be positive, intellectual, and committed to each student individually as well as the community as a whole" (personal email communication, 2013-01-08).
} 
veto or by deciding only for yourself or by some other form - so far these tensions have not led to splitting the class but I can imagine this possibility in the future in the Anarchist OSE. In my view, this possible development is not necessary a big deal in an Anarchist OSE class although it may require development of new organizational and instructional forms. Even more, an Anarchist OSE teacher may actively suggest the students splitting their learning community as the existing collectivity may be atavistic of totalizing non-negotiable imposition remained unrevised from a conventional education.

I think that the Communitarian OSE may have a potential for more spreading and for more stability in the future as it may have easier life of being accepted by conventional educational institutions [unless it can erupt into excesses of the cult of teacher personality or totalitarian tendencies (see, for example, Jones, 1972)] than the Anarchist OSE. In the context of conventional educational institution, the Communitarian OSE has much more chances to survive than the Anarchist OSE because, on the one hand, it provides a high quality of critical dialogue and a high level student learning activism but, on the other hand, it can be shaped by the same educational practices as the conventional educational institutions but coming from the OSE students' democratic decision making. In contrast to the Anarchist OSE and in accord with conventional institutions, the Communitarian OSE non-negotiably imposes important learning activities on all students through its peer communal pressure and demands. To some degree, the Communitarian OSE looks like an organic hybrid between a conventional education and democratic education focusing on critical dialogue. The question that I have is at what point the imposed collectivity of "mutual accountability" starts limiting critical dialogue, shielding some truths from being testable, - is it unavoidable in the Communitarian OSE? Does it happen in Scott's classes as it did happen in Makarenko's institutions and the Communard education movement in the Soviet Union?

\section{Dialogic objectivizing approach: A Proposal}

Finally, I want to share and propose for your consideration my half-baked ideas about another promising approach to the issue of non-negotiable imposition in education that my colleague Mark Smith and I (Matusov, 2009, ch. 8) have developed in our critical response to Vivian Paley's thought-provoking and insightful book You can't say you can't play (Paley, 1992). Paley, a teacher of 4-year old preschoolers was concerned with some of her, mostly minority, kids being systematically excluded from other children's play. She masterfully engaged her children in a discussion of this problem but then suddenly abandoned the collective search for a solution because she realized her urgent responsibility for social justice as a preschool teacher. Criticizing Paley's abrupt and, arguably, authoritarian shift to totalizing non-negotiable imposition of the forced inclusion rule, "You can't say you can't play" on her preschoolers, we proposed more acceptable alternatives that we called "dialogic objectivizing." Bakhtin defined objectivizing by treating other people as objects of one's actions rather than as addressees in a dialogue (Bakhtin, 1999). Thus, on the first glance, our concept of "dialogic objectivizing" sounds like a misnomer, a contradiction in terms. Dialogic objectivizing involves non-negotiable imposition in order for the person to evaluate ontologically, through his or her experiences, what diverse ontological conditions he or she prefers and why,

\footnotetext{
Dialogic objectivizing is tricking (manipulative forcing) a person into testing his or her person-idea. For example, when I (Eugene Matusov, the first author of this chapter) was a 5-year old child my parents wanted me to taste smoked fish that smelled and looked not appealing for me. So I refused to try. Then, my parents decided to bribe me by offering a chocolate candy, I liked a lot, if I ate one smoked fish. After some hesitation, I made a bite and... I found that I liked the smoked fish. I ate one fish after another without any bribe. This case is arguably dialogic objectivizing. Although I was forced into a new ontological situation of tasting initially unattractive food, my parents gave me safe retreat if the experiment had failed and I would not have liked the
} 
smoked fish. This is very different than in a case of monologic social engineering ${ }^{29}$ when people are tricked or manipulatively forced into a new ontological situation from which they do not have a safe escape anymore. For example, in Sánta's (1986) fiction novel "The fifth seal" the action occurred during the WWII Hungarian Nazi terror in the fall of 1944. One character, a photographer and a former soldier from the Russian front injured in the war, decided to "trick" four local "lay" people whom he met occasionally in a pub into moral consideration of their own "empty" being. He wanted them to stop mental chewing of their everyday prosaic trifle issues (or at least this was how he perceived their conversations) that highly irritated him and instead to turn themselves toward consideration of "ultimate questions" of morality. For this purpose, he socially engineered their ontological being - he reported on them to the Hungarian version of German Gestapo that they had shared several anti-government jokes and spoken disrespectfully about the Hungarian Nazi regime. The four pub attendees were immediately arrested. They indeed faced with ultimate questions of morality in the Nazi prison and were forced to make their moral choices on a threshold of their physical and moral life. In this extreme case, photographer's social engineering was very successful. Monologic social engineering canalizes ontological being of people to pattern their person-ideas in a certain, often predesigned, way (cf. building a "new Soviet man" as a project of social engineering in the Stalinist USSR, van der Veer \& Valsiner, 1991). It does not provide any choice to people (or provides only fake choices). It is important to notice that the photographer trapped his victims without any loophole of a safe escape or return to the previous circumstance of their prosaic everyday life which always gives a genuine choice (unfinalizing) to the participants. In our view, in this important moment of absence of any trap dialogic objectivizing is different from monologic social engineering (Matusov, 2009, pp. 250-251).

Smith and I suggest two types of dialogic objectivizing: 1) temporal, in which students are imposed to experience two or more different ontological conditions for their future evaluation sequentially in time (my fish example is like that) and 2) spatial, in which students are presented with two or more different ontological conditions for their future evaluation in diverse spaces, "when people are tricked [or made] into a new ontological locale so they can freely compare and choose lives in the old and new ontological locales" (p. 260). The latter is illustrated in Paley's book by her teaching aide, "who set a play inclusive rule in her backyard for neighborhood children: the children could come and play in her backyard only if they allow other kids to play. Thus, they had a choice either to accept the inclusive rule or to go elsewhere to play having their exclusion right" (Matusov, 2009, p. 274). Thus, in dialogic objectivizing, imposition is non-negotiable locally by making students try alternative ontological conditions; while globally it remains negotiable because at the end of the day, the students remain the final authority for their own education as they made an informative decision about their preferences for these alternative conditions (or for moving away from all of them or for designing new ontological conditions).

Non-negotiable imposition of dialogic objectivizing seems to help to overcome the limitations of exclusively negotiable impositions of the Anarchist, Communitarian, and Libertarian approaches as it can provide students with opportunities to try something new that they may not try otherwise, with serendipity of discovering something important and attractive on the periphery of their new experiences, with making ontological choices, with experiencing collective focus in learning activities, and with utilizing the teacher's epistemological and ontological authority. It seems also to overcome limitations of the Totalitarian and Capitalist approaches as it promotes ontological and intellectual Internally Persuasive Discourse in education and about the students' education and nurtures the students' agency and respects the students' autonomy (on the global, but not local, scale).

One big challenge I see on a way of implementing and trying the Dialogic Objectivizing approach is to design positive incentives, attractive to the students (like my parents bribing me with chocolate candies to make me try smoked fish when I was little), that can trick and make all (or some?) students all

${ }^{29}$ Cf. Rousseau.

Dialogic Pedagogy: An International Online Journal | http://dpj.pitt.edu DOI: 10.5195/dpj.2015.110 | Vol. 3 (2015) 
the time (often? sometimes?) accept temporal or spatial non-negotiable impositions. Currently, in conventional education, incentives are either negative - involving disruption of students' relations with their parents, pressure by peers or the teacher, limiting access to the next level of educational institutions, denying credentials necessary for desired jobs, expulsion, retention, threats, suspensions, and so on, or positive but limited in effectiveness - praises, stickers, token economy, and so on (Sidorkin, 2002, 2009). To address this problem, Sidorkin suggests using two major positive incentives: a) teachers can offer their students extra-curricular socialization, as many sport coaches and some teachers do, and b) monetary compensation for students' cooperation with the teacher's unconditional and unilateral demands. Although I am very sympathetic with Sidorkin's search for positive and effective incentives for teachers' non-negotiable imposition in education, so far I have found his interesting suggestions impractical for my particular teaching circumstances of conventional university education. Based on the student's comments above I would incentivize collective action/assignments and even some content areas, but like my fish example, there ought to be a loophole so if students don't like it after a period of forced engagement, they can drop it. Equally, if taken up, the incentives should drop off as unnecessary. Unfortunately, so far I cannot think of good alternatives as I am eager to start designing and testing the Dialogic Objectivizing approach to non-negotiable imposition in education in my own pedagogical practice.

\section{Conclusions}

It is apparent that there are diverse approaches that define and promote the particular values of good education. Thus, for example, the Totalizing, Capitalist, and Progressive approaches to nonnegotiable imposition to education assume the societal unilateral control over the educational curriculum; while the Libertarian approach insists on the student's autonomous decision on the curriculum (unless the student chooses to surrender it to the teacher). The Anarchist, Communitarian, and Dialogic Objectivizing approaches focus more on collaboration between the teacher and the students. In contrast to the three former approaches, the three latter approaches - the Libertarian, Anarchist, Communitarian, and Dialogic Objectivizing - imply more diversification of education with its overall goals focusing on education as praxis (i.e., Aristotle's term for activity in which its final goals, values, and qualities are defined and emerge in the activity itself) and argue for Philosophical Pluralism in Education. The Totalizing, Capitalist, and Progressive approaches apparently view education as poïesis (i.e., Aristotle's term for activity in which its final goals, values, qualities, and curricula are pre-defined in advance of the activity itself) and fight for their own Philosophical Monopoly on Education. The Anarchist and Dialogic Objectivizing approaches highly value unfettered critical dialogue among the students and the teacher about value of the education itself and involved studied practices of what Marjanovic-Shane and I call praxis of praxis (Matusov \& Marjanovic-Shane, 2012). In contrast to the Totalizing approach (and to some degree Communitarian approach), the Capitalist and Progressive approaches (and the other three) call for more sensitivity for students' needs and against pedagogical violence. The Progressive, Libertarian, Anarchist, Communitarian, and Dialogic Objectivizing approaches are concerned with students' alienation from their learning and, in contrast to Sidorkin's Capitalist approach, agree that this alienation can be successfully addressed. These disagreements and alliances among the approaches may arguably constitute the complex politics in the educational sphere and can also create interesting hybrids and synergies as well as tensions - to be studied in the future. Another related issue is how all these approaches interact with local and global cultures and cultural tensions, "Is non-negotiable imposition in education a must for certain kinds of societies, certain modes of production, and the need of certain kind of laborers? Could attempts to resist a different kind of education be attempts to resist a certain direction to which policy makers want education to go for the benefit of certain structures?" (Nermine Abd Elkader, personal communication, 2012-11-19).

Dialogic Pedagogy: An International Online Journal | http://dpj.pitt.edu DOI: 10.5195/dpj.2015.110 | Vol. 3 (2015) 
Finally, one important and relevant issue left out by the article, but still demanding our discussion, is non-negotiable imposition of education on people per se. The majority of modern societies nonnegotiably impose education on all of its citizens. Socrates famously insisted that the unexamined life is not worth living (Plato, 1997). Kukathas disagrees, arguing that people may have a good life, defined by living according to their conscience, without critical examination of their life, practices, or the world and that non-negotiable imposition of education on these people constitutes illegitimate violence. Even more, critical education may undermine and destroy their good life (Kukathas, 2001b, 2003). In contrast to the Totalizing, Capitalist, Progressive, and Communitarian approaches, the Libertarian, Anarchist, and Dialogic Objectivizing approaches all value the legitimacy of students' non-participation and noncollaboration with the teacher and with the idea of education. However, so far and as far as I know, only the Libertarian approach has fully practiced this principle in life (Greenberg, 1991, 1992b; Neill, 1960). Even more, I have sensed that the Libertarian approach is less concerned with the Education Project altogether focusing instead on "a radical approach to child rearing" (Summerhill, Neill, 1960), participation in democracy, democratic institutions, and democratic governance (Sudbury Valley School, Greenberg, 1992a), or civic engagement in "scaled down society" (The Circle School, Rietmulder, 2009). Arguably, the value and need for "education" can be overrated and artificially ${ }^{30}$ and illegitimately imposed on all people in modern society. The society may need to provide resources for education for all but not necessarily educational control or overall non-negotiable imposition of education (Kukathas, 2001a; Matusov \& Marjanovic-Shane, 2011). More discussion and investigation of this important issue of limitations and (un)desirability of education is needed.

\section{References}

Allen, B., Getzels, P., \& Getzels, H. G. (1992). Summerhill at 70 [videorecording]. New York; Princeton, NJ: Middlemarch Films for Channel 4; Films for the Humanities \& Sciences, Inc.

Arendt, H. (1958). The human condition. Chicago: University of Chicago Press.

Avila, E. B. d., Caron, T., Flanagan, P. A., Frer, D., Heaney, T., Hyland, N., et al. (2001). Learning democracy/democratizing learning: Participatory graduate education. In P. Campbell \& B. Burnaby (Eds.), Participatory practices in adult education (pp. 221-236). Mahwah, NJ: Lawrence Erlbaum Associates.

Bakhtin, M. M. (1991). Dialogic imagination: Four essays by M. M. Bakhtin (C. Emerson \& M. Holquist, Trans.). Austin, TX: University of Texas Press.

Bakhtin, M. M. (1999). Problems of Dostoevsky's poetics (Vol. 8). Minneapolis: University of Minnesota Press.

Bourdieu, P. (1990). In other words: Essays towards a reflexive sociology. Stanford, CA: Stanford University Press.

Bruner, J. (1986). Actual minds, possible words. Cambridge, MA: Harvard University Press.

Caskey, B. (1979). The pedagogical theories of A. S. Makarenko: A comparative analysis. Comparative Education, 15(3), 277-286.

Collins, A., \& Halverson, R. (2009). Rethinking education in the age of technology: The digital revolution and schooling in America. New York: Teachers College Press.

\footnotetext{
${ }^{30}$ Thus, in the US, job descriptions for an animal keeper in a zoo, a night guard, an assistant to elderly people, and so on often require a High School diploma. I suspect that it is not the case that jobs for people without institutionalized education has disappeared as some educationalists, politicians, and pundits argue, but rather these jobs have become more and more artificially and illegitimately dependent upon educational credentials in their descriptions making the lives of people without these unnecessary credentials truly miserable. I wonder if societal and legal supervision of the job's excessive educational requirements is necessary.
} 
Dewey, J. (1956). The child and the curriculum and the school and society (Combined ed.). Chicago: University of Chicago Press.

Diederich, P., \& Hampel, R. L. (2014). Paul Diederich and the progressive American high school, 19301970. Charlotte, NC: IAP - Information Age Publishing.

Eckert, P. (1989). Jocks and burnouts: Social categories and identity in the high school. New York: Teachers College Press.

Farber, J. (1970). The student as Nigger: Essays and stories. New York: Pocket Books.

Fendler, L. (1998). What is it impossible to think? A genealogy of the educated subject. In T. S. Popkewitz \& M. Brennan (Eds.), Foucault's challenge: Discourse, knowledge, and power in education (pp. 39-63). New York: Teachers College Press.

Ferrer Guardia, F. (1972). The origin and ideals of the modern school. New York: Arno Press.

Ford, M. (2015). Rise of the robots: Technology and the threat of a jobless future. New York: Basic Books.

Gee, J. P. (1996). Social linguistics and literacies: Ideology in discourses (2nd ed.). London: Taylor \& Francis.

Glaser, B. G., \& Strauss, A. L. (1967). The discovery of grounded theory: Strategies for qualitative research. Chicago: Aldine Publishing Co.

Golding, W. (1999). Lord of the flies: A novel. New York: Penguin.

Gorz, A. (1989). Critique of economic reason. London: Verso.

Greenberg, D. (1991). Free at last: The Sudbury Valley School. Framingham, MA: Sudbury Valley School Press.

Greenberg, D. (1992a). The birth of a new paradigm for education. Retrieved from http://www.sudval.com/05_underlyingideas.html\#05

Greenberg, D. (1992b). The Sudbury Valley School experience. Framingham, MA: Sudbury Valley School Press.

Hayek, F. A. v. (1994). The road to serfdom. Chicago: University of Chicago Press.

Hirsch, E. D. (1996). The schools we need and why we don't have them (1st ed.). New York: Doubleday.

Hirsch, E. D., Trefil, J. S., \& Kett, J. F. (1988). Cultural literacy: What every American needs to know (1st Vintage Books ed.). New York: Vintage Books.

Holt, J. C. (1972). Freedom and beyond ([1st ed.). New York: E. P. Dutton.

Huizinga, J. (2009). Homo ludens: A study of the play-element in culture. Oxon U.K.: Routledge.

Illich, I. (1983). Deschooling society (1st Harper Colophon ed.). New York: Harper Colophon.

Jackson, P. W. (1968). Life in classrooms. New York: Holt Rinehart and Winston.

Jones, R. (1972). The Third Wave, 1967, an account - Ron Jones. Retrieved from Libcom.org website: http://libcom.org/history/the-third-wave-1967-account-ron-jones

Kamii, C. (1991). Toward autonomy: The importance of critical thinking and choice making. School Psychology Review, 20(3), 382-388.

Kennedy, M. M. (2005). Inside teaching: How classroom life undermines reform. Cambridge, MA: Harvard University Press.

Klag, P. (1994). A new look at Invitational Education. The Collaborator, 5(14), 1-2.

Kleindienst, B. (1998). The children of Summerhill. New York: Cinema Guild.

Kohn, A. (2014). The myth of the spoiled child: Challenging the conventional wisdom about children and parenting. Boston, MA: Da Capo Lifelong.

Kukathas, C. (2001a). Education and citizenship in diverse societies. International Journal of Educational Research, 35(3), 319-330.

Kukathas, C. (2001b). Passing the unexamined life. Quadrant, 45(7), 22-24.

Kukathas, C. (2003). The liberal archipelago: A theory of diversity and freedom. Oxford: Oxford University Press. 


\section{Legitimacy of non-negotiable imposition in diverse approaches to education}

Eugene Matusov

Labaree, D. F. (1997). How to succeed in school without really learning: The credentials race in American education. New Haven, CT: Yale University Press.

Labaree, D. F. (2010). Someone has to fail: The zero-sum game of public schooling. Cambridge, MA: Harvard University Press.

Lareau, A. (2003). Unequal childhoods: Class, race, and family life. Berkeley: University of California Press.

Lave, J. (1988). Cognition in practice: Mind, mathematics, and culture in everyday life. Cambridge, UK: Cambridge University Press.

Lave, J. (1992). Word problems: A microcosm of theories of learning. In P. Light \& G. Butterworth (Eds.), Context and cognition: Ways of learning and knowing. (pp. 74-92). Hillsdale, NJ: Lawrence Erlbaum Associates, Inc.

Linn, M. C. (1985). Fostering equitable consequences from computer learning environments. Sex Roles, 13(3-4), 229-240.

Llewellyn, G. (1998). The teenage liberation handbook: How to quit school and get a real life and education (Rev., 2nd ed ed.). Eugene, OR: Lowry House.

Makarenko, A. S. (1973). The road to life: An epic in education. New York: Oriole Editions.

Mandela, N. (1995). Long walk to freedom: The autobiography of Nelson Mandela. London: Abacus.

Marjanovic-Shane, A. (2015, in preparation). "Spoilsport" in drama education vs. dialogic pedagogy.

Marjanovic-Shane, A., \& Matusov, E. (2012, October). Metamorphosis of pedagogical desire: Transformation of self in becoming a dialogic teacher. Paper presented at the International Conference on Dialogical Self, Atlanta, Georgia.

Matusov, E. (2007). Applying Bakhtin scholarship on discourse in education: A critical review essay. Educational Theory, 57(2), 215-237. doi: http://dx.doi.org/10.1111/j.1741-5446.2007.00253.x

Matusov, E. (2009). Journey into dialogic pedagogy. Hauppauge, NY: Nova Science Publishers.

Matusov, E. (2011). Authorial teaching and learning. In E. J. White \& M. Peters (Eds.), Bakhtinian pedagogy: Opportunities and challenges for research, policy and practice in education across the globe (pp. 21-46). New York: Peter Lang Publishers.

Matusov, E. (2015). Chronotopes in education: Conventional and dialogic. Dialogic Pedagogy: An International Online Journal, 3, A65-A97. doi: 10.5195/dpj.2015.107

Matusov, E., \& Brobst, J. (2013). Radical experiment in dialogic pedagogy in higher education and its centaur failure: Chronotopic analysis. Hauppauge, NY: Nova Science Publishers.

Matusov, E., \& Marjanovic-Shane, A. (2011). The State's Educational Neutrality and Educational Pluralism: A revolution proposal. Retrieved from Dialogic Pedagogy website: http://diaped.soe.udel.edu/dp-map/?page_id=676

Matusov, E., \& Marjanovic-Shane, A. (2012). Diverse approaches to education: Alienated learning, closed and open participatory socialization, and critical dialogue. Human Development, 55(3), 159-166. doi: $10.1159 / 000339594$

Matusov, E., \& Marjanovic-Shane, A. (2012, March). Radical experiment in dialogic pedagogy: Building a Democratic Community of Learners through Open Syllabus. Paper presented at the International Mini-Bakhtinian conference on Dialogic Pedagogy, Newark, Delaware.

Matusov, E., \& von Duyke, K. (2010). Bakhtin's notion of the Internally Persuasive Discourse in education: Internal to what? (A case of discussion of issues of foul language in teacher education). In K. Junefelt \& P. Nordin (Eds.), Proceedings from the Second International Interdisciplinary Conference on perspectives and limits of dialogism in Mikhail Bakhtin Stockholm University, Sweden June 3-5, 2009 (pp. 174-199). Stockholm: Stockholm University.

Matusov, E., von Duyke, K., \& Han, S. (2012). Community of Learners: Ontological and non-ontological projects. Outlines: Critical Social Studies, 14(1), 41-72.

Mazur, E. (1997). Peer instruction: A user's manual. Upper Saddle River, NJ: Prentice Hall. 
McLaren, P. (1993). Schooling as a ritual performance: Towards a political economy of educational symbols and gestures (2nd ed.). London; New York: Routledge.

Moore, M. (2009). On the roots of teaching and learning. ETC: A Review of General Semantics 66(4), $422-428$.

Morrison, K. A. (2007). Free school teaching: A journey into radical progressive education. Albany: State University of New York Press.

Morson, G. S. (2004). The process of ideological becoming. In A. F. Ball \& S. W. Freedman (Eds.), Bakhtinian perspectives on language, literacy, and learning (pp. 317-331). Cambridge, UK; New York: Cambridge University Press.

Neill, A. S. (1960). Summerhill: A radical approach to child rearing. New York: Hart Publishing Company.

Paley, V. G. (1992). You can't say you can't play. Cambridge, MA: Harvard University Press.

Phillips, C. (2002). Socrates café: A fresh taste of philosophy. New York: W.W. Norton.

Plato. (1997). Complete works (J. M. Cooper \& D. S. Hutchinson, Trans.). Indianapolis, IN: Hackett Pub. Plato, \& Bluck, R. S. (1961). Meno. Cambridge, UK: University Press.

Powell, A. G., Farrar, E., \& Cohen, D. K. (1985). The shopping mall high school: Winners and losers in the educational marketplace. Boston: Houghton Mifflin.

Rancière, J. (1991). The ignorant schoolmaster: Five lessons in intellectual emancipation (K. Ross, Trans.). Stanford, CA: Stanford University Press.

Rietmulder, J. (2009). The Circle School: An introduction to integral education ideas and practices. Harrisburg PA: The Circle School.

Rogoff, B. (2003). The cultural nature of human development. New York: Oxford University Press.

Rousseau, J. J. (1979). Emile: or, On education. New York: Basic Books.

Shor, I. (1996). When students have power: Negotiating authority in a critical pedagogy. Chicago: University of Chicago Press.

Sidorkin, A. M. (1995). The Communard movement in Russia: The view of a participant. East-West Education, 16(2), 148-159.

Sidorkin, A. M. (2002). Learning relations: Impure education, deschooled schools, \& dialogue with evil. New York: P. Lang.

Sidorkin, A. M. (2009). Labor of learning: Market and the next generation of education reform. Rotterdam, the Netherlands: Sense Publishers.

Smith, M. P., \& Correa, C. (2012, February). Challenges of students' agency within a Community of Learners: The cases of a university graduate course and an adult English language classroom.

Paper presented at the Ethnography in Education Research Forum, , Philadelphia, Pennsylvania.

Smith, M. P., \& Matusov, E. (2010). A proposal for a new schooling: Hybrid of reciprocity and authentic dialogue. Review of the book [Sidorkin, A. M. (2002). Learning relations: Impure education, deschooled schools, \& dialogue with evil. New York: P. Lang.]. Mind, Culture and Activity, 18(3), 297-300.

Suissa, J. (2010). Anarchism and education a philosophical perspective. Oakland, CA: PM Press.

Trevino, R. E. (2004). Against All Odds: Lessons from Parents of Migrant High-Achievers (pp. 16-16).

von Duyke, K. (2013). Students' agency, autonomy, and emergent learning interests in two open democratic schools. PhD, Univrsity of Delaware.

Waller, W. W. (1932). The sociology of teaching. New York: J. Wiley \& sons.

Willis, P. E. (1981). Learning to labor: How working class kids get working class jobs (Morningside ed.). New York: Columbia University Press. 


\section{(c)) EY}

New articles in this journal are licensed under a Creative Commons Attribution 4.0 United States License.

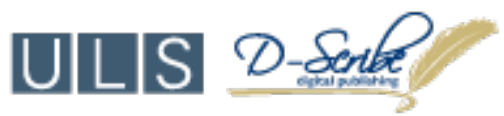

This journal is published by the University Library System, University of Pittsburgh as part of its D-Scribe Digital Publishing Program and is cosponsored by the University of Pittsburgh Press. 